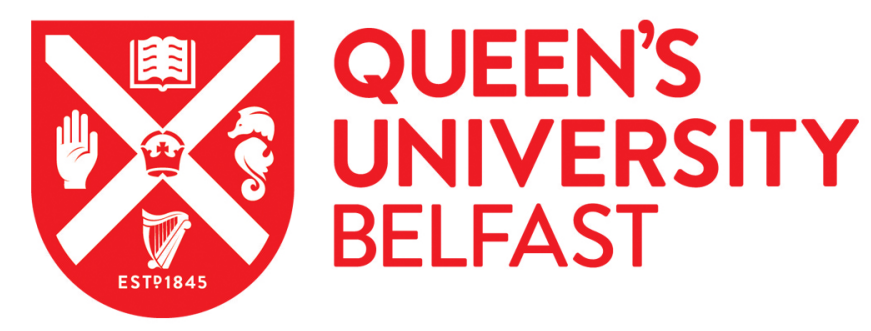

\title{
Design and Synthesis of Heteroleptic Iridium(III) Phosphors for Efficient Organic Light-Emitting Devices
}

Kumar, S., Surati, K. R., Lawrence, R., Vamja, A. C., Yakunin, S., Kovalenko, M. V., Santos, E. J. G., \& Shih, CJ. (2017). Design and Synthesis of Heteroleptic Iridium(III) Phosphors for Efficient Organic Light-Emitting Devices. Inorganic Chemistry. https://doi.org/10.1021/acs.inorgchem.7b02872

Published in:

Inorganic Chemistry

Document Version:

Peer reviewed version

Queen's University Belfast - Research Portal:

Link to publication record in Queen's University Belfast Research Portal

Publisher rights

Copyright (C) 2017 American Chemical Society. This work is made available online in accordance with the publisher's policies. Please refer to any applicable terms of use of the publisher.

\section{General rights}

Copyright for the publications made accessible via the Queen's University Belfast Research Portal is retained by the author(s) and / or other copyright owners and it is a condition of accessing these publications that users recognise and abide by the legal requirements associated with these rights.

Take down policy

The Research Portal is Queen's institutional repository that provides access to Queen's research output. Every effort has been made to ensure that content in the Research Portal does not infringe any person's rights, or applicable UK laws. If you discover content in the Research Portal that you believe breaches copyright or violates any law, please contact openaccess@qub.ac.uk. 


\title{
Design and Synthesis of Heteroleptic Iridium (III) Phosphors for Efficient Organic Light Emitting Devices
}

\author{
Sudhir Kumar ${ }^{\dagger}$, K. R. Surati ${ }^{\ddagger}$, Robert Lawrence ${ }^{\S}$, Atul C. Vamja ${ }^{\ddagger}$, Sergii Yakunin ${ }^{\natural \pm}$, \\ Maksym V. Kovalenko ${ }^{\llbracket, \pm}$, Elton J.G. Santos ${ }^{\S}$, and Chih-Jen Shih ${ }^{\dagger, *}$ \\ ${ }^{\dagger}$ Institute for Chemical and Bioengineering, ETH Zürich, 8093 Zürich, Switzerland \\ ${ }^{*}$ Department of Chemistry, Sardar Patel University, Vallabh Vidyanagar, Gujarat, India \\ ${ }^{\S}$ School of Mathematics and Physics, Queen's University Belfast, BT7 1NN, United Kingdom \\ ${ }^{\circledR}$ Laboratory of Inorganic Chemistry, ETH Zürich, 8093 Zürich, Switzerland \\ ${ }^{ \pm}$Empa - Swiss Federal Laboratories for Materials Science and Technology, CH-8600 Dübendorf, Switzerland \\ *Author to whom all correspondence should be addressed. Email: chih-jen.shih@chem.ethz.ch
}

\begin{abstract}
The phosphorescent emitters are essential to realize energy-efficient display and lighting panels. The solution processability is of particular interest for large-scale and low-cost production. Here, we present a series of the heteroleptic iridium (Ir) complexes, $\operatorname{Ir}(\text { ppy })_{2} L 1, \operatorname{Ir}(\text { ppy })_{2} \mathrm{~L} 2$, and $\operatorname{Ir}(\text { ppy })_{2}$ L3, using the new ancillary ligands, including 1-(2-chlorophenyl)-5-hydroxy-3-methyl1H-pyrazole-4-carbaldehyde (L1), 5-hydroxy-3-methyl-1-(p-tolyl)-1H-pyrazole-4-carbaldehyde (L2), and 5-hydroxy-3-methyl-1-phenyl-1H-pyrazole-4-carbaldehyde (L3). Their photophysical and electrochemical properties were systematically characterized, followed by comparing with those predicted by density functional theory (DFT) simulations using hybrid functionals. Among the three phosphors synthesized, $\operatorname{Ir}(\mathrm{ppy})_{2} \mathrm{~L} 1$ exhibits the highest photoluminescence quantum yield $\left(\Phi_{P L}=89 \%\right)$, with an exciton lifetime of $0.34 \mu$ s. By using 4,4'-bis(carbazole-9-yl)biphenyl as the host material, we demonstrate high current efficiencies of $64 \mathrm{~cd} \mathrm{~A}^{-1}$ and $40 \mathrm{~cd} \mathrm{~A}^{-1}$ at 100 $\mathrm{cd} \mathrm{m}^{-2}$ in its vacuum-evaporated and solution-processed organic light-emitting devices, respectively, revealing the promise for large-area light sources.
\end{abstract}

\section{Introduction}


In spite of the fact that the organic light emitting diodes (OLEDs) technology has been successfully commercialized for more than one decade, ${ }^{1-3}$ advanced research in understanding and engineering its performance index remains active to meet requirements of different applications, such as solid-state lightings and flat panel displays. Specifically, three main strategies have been utilized to enhance the device efficiencies, including: (i) molecular design of new high-quantum-yield emitters, bipolar hosts, and high-mobility transport materials, ${ }^{4-6}$ (ii) the new device architectures that promotes carrier recombination and confinement within the emissive layer, ${ }^{3}$ and (iii) the techniques that induces an efficient light out-coupling. ${ }^{3,7,8}$ In terms of the emitters, the phosphorescent organometallic compounds have been considered as a promising candidate, since one can in principle, harvest $100 \%$ of the excitons through a strong spin-orbit coupling (SOC) induced by the heavy metals, such as iridium (Ir), platinum (Pt), osmium (Os) and ruthenium (Ru). ${ }^{9,10}$ The phenylpyridine complexes of iridium are of particular interest based on the observations of fast intersystem crossing (ISC) and relatively short exciton lifetime $(\tau),{ }^{11}$ which result from the strong triplet metal-to-ligand charge transfer $\left({ }^{3} \mathrm{MLCT}\right) .{ }^{12}$ Recent findings in designing new Ir-based phosphors have further suggested that both cyclometalated and ancillary ligands profoundly influence the photophysical and electrochemical characteristics. ${ }^{13}$ Since the first demonstration of phosphorescent OLED in 1998 using a homoleptic iridium complex of $f a c$-tris[2-phenylpyridinato-C2,N]iridium(III) $\left(\operatorname{Ir}(\mathrm{ppy})_{3}\right),{ }^{14}$ several homoleptic and heteroleptic iridium complexes have been synthesized and employed in devices. ${ }^{3,4,15}$ For example, Kim et al. reported a maximum power efficiency $\left(\eta_{P E}\right)$ of $22.6 \mathrm{~lm} \mathrm{~W}^{-1}$ with a homoleptic tris-cyclometalated $\mathrm{Ir}(\mathrm{III})$ complex. ${ }^{16} \mathrm{Xu}$ et al. reached $\eta_{P E}$ of $43.6 \mathrm{~lm} \mathrm{~W}^{-1}$ with a bis-cyclometalated iridium complex containing an organic ligand trifluoromethyl substituted bipyridine (2',6'-bis-(trifluoromethyl)-2,3'-bipyridine. ${ }^{17}$ A series of Ir complexes 
with the tetra(4-trifluoromethylpheny) imidodiphosphinate (tfmtpip), tetraphenylimidodiphosphinate (tpip), and trifluoromethylphenyl-pyridine (tfmppy) organic ligands have been demonstrated, which resulted the high performance OLED devices. ${ }^{18}$ Jou et al. reported a $\eta_{P E}$ of $61 \mathrm{~lm} \mathrm{~W}^{-1}$ using a heteroleptic iridium phosphor bis [5-methyl-8trifluoromethyl-5H-benzo(c) (1,5)naphthyridin-6-one]iridium(pyrazinecarboxylate) $\quad(\operatorname{Ir}(3-$ $\left.\mathrm{CF}_{3} \mathrm{BNO}\right)_{2}($ prz) $)$ in the wet-processed OLEDs. ${ }^{19}$ Tong et al. also demonstrated a high photoluminescence quantum yield $\left(\Phi_{P L}\right)$ of $72 \%$ and a $\eta_{P E}$ of $35.5 \mathrm{~lm} \mathrm{~W}^{-1}$ with the iridium complex, using two organic ligand groups, 1,3-difluoro-4,6-di(pyridin-2-yl) benzene and 2-(5trifluoromethyl-1H-pyrazol-3-yl)-6-(4-trifluoromethylphenyl) pyridine. ${ }^{20}$ Zhang et al. designed a green heteroleptic Ir complex, $\operatorname{Ir}(\mathrm{ppy})_{2}(\mathrm{POXD})$, by using an ancillary ligand $N$-(5-phenyl-1,3,4oxadiazol-2-yl)-diphenyl phosphinic amide. The $\operatorname{Ir}(\mathrm{ppy})_{2}(\mathrm{POXD})$ emitter shows a $\eta_{P E}$ of $42.5 \mathrm{~lm}$ $\mathrm{W}^{-1}$ for dry-processed OLED device. ${ }^{21}$

The light emitting devices are often fabricated by thermally evaporating or spin-coating the phosphorescent emitters in a layer-by-layer manner. ${ }^{3,12}$ Nevertheless, very few emitters can exhibit high efficiencies with both processes. ${ }^{22}$ Considering the fact that the deposition process of an emitter largely depends on the thermal stability and solubility, ${ }^{22}$ there is a clear need to devise the new Ir-complexes that enable high-efficiency devices with versatile process methods, in order to address the challenges associated with the low-cost, roll-to-roll fabrication of OLEDs. Here, we designed and synthesized a series of heteroleptic iridium complexes by employing the typical 2-phenylpyridine cyclometalated ligand with three new ancillary ligands, including 1-(2chlorophenyl)-5-hydroxy-3-methyl-1H-pyrazole-4-carbaldehyde (L1), 5-hydroxy-3-methyl-1-(ptolyl)-1H-pyrazole-4-carbaldehyde (L2) and 5-hydroxy-3-methyl-1-phenyl-1H-pyrazole-4carbaldehyde (L3). The synthesized complexes, namely, $\operatorname{Ir}(\mathrm{ppy})_{2} \mathrm{~L} 1, \operatorname{Ir}(\mathrm{ppy})_{2} \mathrm{~L} 2$, and $\operatorname{Ir}(\mathrm{ppy})_{2} \mathrm{~L} 3$, 
possess high solubility in common organic solvents and proper thermal behavior, which allow facile film formation through the solution processes or thermal evaporation. Among the three materials considered, we achieve the best efficiencies with the $\operatorname{Ir}(\mathrm{ppy})_{2} \mathrm{~L} 1$ green emitter, with a current efficiency $\left(\eta_{C E}\right)$ of $64 \mathrm{~cd} \mathrm{~A}^{-1}$ and a $\eta_{P E}$ of $48 \mathrm{~lm} \mathrm{~W}^{-1}$, at $100 \mathrm{~cd} \mathrm{~m}^{-2}$, in the thermalevaporated devices. Moreover, we report comparable efficiencies in the solution-processed devices $\left(\eta_{C E}=46 \mathrm{~cd} \mathrm{~A}^{-1}\right.$ and $\eta_{P E}=29 \mathrm{~lm} \mathrm{~W}^{-1}$ at $\left.1000 \mathrm{~cd} \mathrm{~m}^{-2}\right)$, confirming the potential in largearea OLED technology.

\section{Results and discussion}

\section{Design and synthesis}

In order to develop the phosphorescent emitters that are compatible with both solution and dry processes, the molecular design concepts are outlined as follows. First, a pyrazole-based chelation motif, which significantly enhances the solubility in the common organic solvents without compromising the thermal stability during evaporation, ${ }^{23} \mathrm{Next}$, an electron-withdrawing chlorine atom (-Cl), an electron-donating methyl group $\left(-\mathrm{CH}_{3}\right)$, and a relatively electroneutral hydrogen atom $(-\mathrm{H})$, are bound to the phenyl tail (see Scheme 1), corresponding to the L1, L2, and $\mathbf{L 3}$ ancillary ligands used in this report, respectively. Such variation of ligand structure is anticipated to modulate the electron density around the $\operatorname{Ir}(\mathrm{III})$ center, which may allow us to tune the photophysical and electrochemical properties of $\operatorname{Ir}(\mathrm{III})$ complexes. Accordingly, we indeed observed a slightly deep highest occupied molecular orbital (HOMO) level in $\operatorname{Ir}(\mathrm{ppy})_{2} \mathrm{~L} 1$, but did not find a notable difference between $\operatorname{Ir}(\mathrm{ppy})_{2} \mathrm{~L} 2$ and $\operatorname{Ir}(\mathrm{ppy})_{2} \mathrm{~L} 3$. In addition, the electronwithdrawing nature of $\mathbf{L} \mathbf{1}$ also leads to a degree of blueshift in the emission wavelength.

The ancillary ligands (L1, L2, and L3) were synthesized following the protocols reported in literature. ${ }^{24,25}$ The Ir(III) complexes were prepared by the Nonoyama route (see Scheme 1). ${ }^{26}$ 


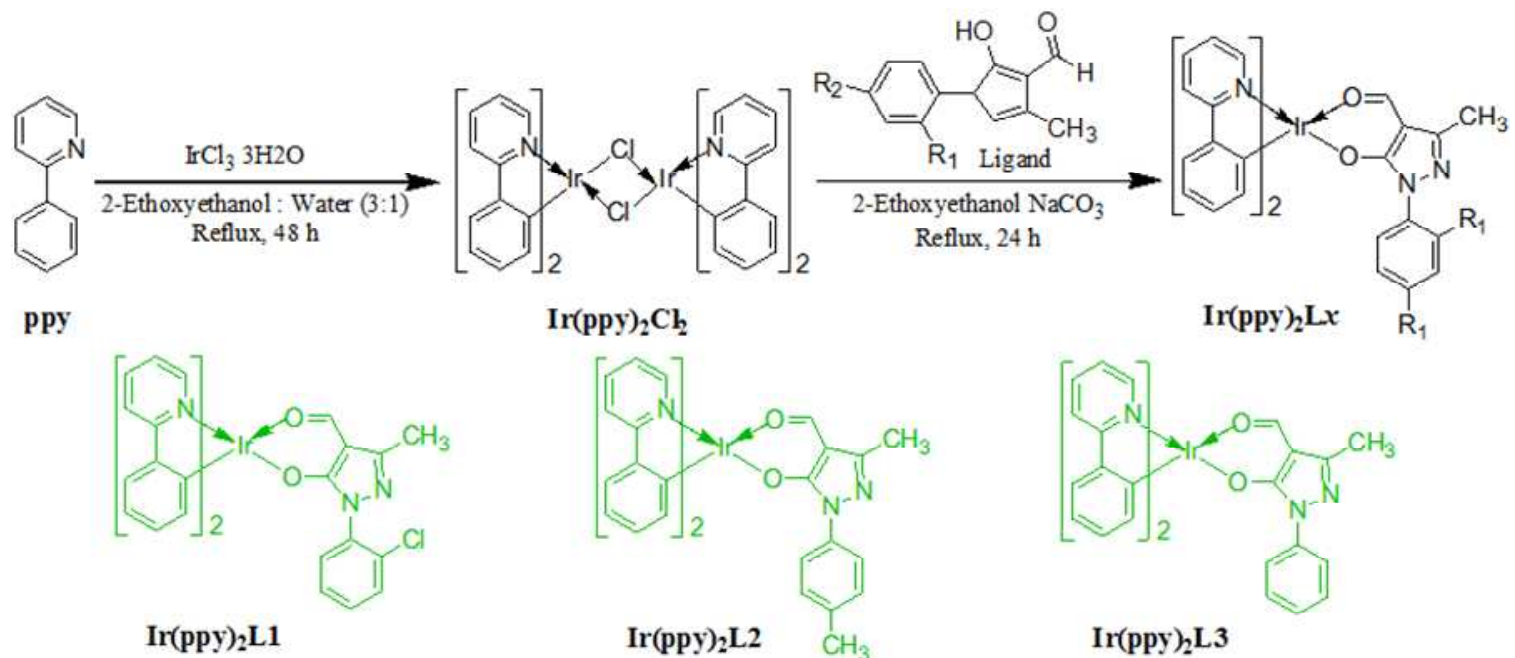

Scheme 1. Synthetic route of the green iridium complexes, $\operatorname{Ir}(p p y)_{2} L 1, \operatorname{Ir}(p p y)_{2} L 2$, and $\operatorname{Ir}(\text { ppy })_{2} \mathrm{~L} 3$.

\section{Thermal properties}

The thermal behavior of the $\operatorname{Ir}(\mathrm{III})$ complexes, $\operatorname{Ir}(\text { ppy })_{2} \mathrm{~L} 1, \operatorname{Ir}(\text { ppy })_{2} \mathrm{~L} 2$, and $\operatorname{Ir}(\mathrm{ppy})_{2} \mathrm{~L} 3$ were characterized by using the differential scanning calorimetry (DSC) and the thermogravimetric analysis (TGA) techniques. As shown in Table 1, the glass transition temperatures $\left(\mathrm{T}_{\mathrm{g}}\right)$ of the novel $\operatorname{Ir}(\mathrm{III})$ complexes are ranged from $235{ }^{\circ} \mathrm{C}$ to $254{ }^{\circ} \mathrm{C}$, and their thermal decomposition temperatures $\left(\mathrm{T}_{\mathrm{d}}\right)$ are ranged from $282{ }^{\circ} \mathrm{C}$, to $301{ }^{\circ} \mathrm{C}$, corresponding to a $5 \%$ weight loss (see Fig. S1 and Fig. S2). The appropriate thermal stability of the Ir(III) complexes prevents a degree of degradation during thermal evaporation, ${ }^{27}$ which is prerequisite for the dry-processed devices.

Table 1. Photophysical, electrochemical, and thermal characteristics of the novel cyclometalated heteroleptic phosphor $\operatorname{Ir}(\mathrm{ppy})_{2} \mathrm{~L} 1$, compared with those of the other two emitters $\operatorname{Ir}(\mathrm{ppy})_{2} \mathrm{~L} 2$ and $\operatorname{Ir}(\mathrm{ppy})_{2} \mathrm{~L} 3$.

\begin{tabular}{|c|c|c|c|c|c|c|c|c|c|c|c|c|c|c|c|c|}
\hline \multirow[t]{2}{*}{ Emitter } & \multirow[t]{2}{*}{$\lambda_{\mathrm{abs}}[\mathrm{nm}]$} & \multicolumn{3}{|c|}{$\lambda_{\mathrm{PL}}[\mathrm{nm}]$} & \multirow{2}{*}{$\begin{array}{l}E_{T}^{\text {b) }} \\
{[\mathrm{eV}]}\end{array}$} & \multirow{2}{*}{$\begin{array}{l}\left.\Phi_{P L} \mathrm{c}\right) \\
(\%)\end{array}$} & \multicolumn{2}{|c|}{$\tau_{\text {avg. }}$ d) $^{(\mu s)}$} & \multicolumn{2}{|c|}{$K_{r},\left(\times 10^{7}\right)$} & \multicolumn{2}{|c|}{$K_{n r}\left(\times 10^{6}\right)$} & \multirow{2}{*}{$\begin{array}{l}T_{\mathrm{g}}^{\mathrm{e})} \\
{\left[{ }^{\circ} \mathrm{C}\right]}\end{array}$} & \multirow{2}{*}{$\begin{array}{l}T_{\mathrm{d}}^{\mathrm{f})} \\
{\left[{ }^{\circ} \mathrm{C}\right]}\end{array}$} & \multirow{2}{*}{$\begin{array}{l}E_{g}^{\mathrm{g})} \\
{[\mathrm{eV}]}\end{array}$} & \multirow{2}{*}{$\begin{array}{l}\text { HOMO/LOMO } \\
{[\mathrm{eV}]}\end{array}$} \\
\hline & & Sol. & Film & Phos. ${ }^{\text {a) }}$ & & & $300 \mathrm{~K}$ & $77 \mathrm{~K}$ & $300 \mathrm{~K}$ & $77 \mathrm{~K}$ & $300 \mathrm{~K}$ & $77 \mathrm{~K}$ & & & & \\
\hline $\operatorname{Ir}(\text { ppy })_{2} \mathrm{~L} 1$ & 262,283 & 511 & 516 & 500,533 & 2.48 & 89 & 0.117 & 0.34 & 7.61 & 0.26 & 9.44 & 0.326 & 235 & 301 & 2.43 & $-4.70 /-2.27$ \\
\hline $\operatorname{Ir}(\text { ppy })_{2} \mathrm{~L} 2$ & 265,283 & 512 & 518 & 499,534 & 2.49 & 42 & 0.198 & 0.13 & 2.12 & 0.32 & 29.3 & 4.38 & 254 & 288 & 2.48 & $-4.90 /-2.42$ \\
\hline $\operatorname{Ir}(\text { ppy })_{2} \mathrm{~L} 3$ & 260,302 & 512 & 516 & 497,533 & 2.50 & 41 & 0.272 & 0.17 & 1.51 & 0.24 & 21.7 & 3.46 & 251 & 282 & 2.46 & $-4.88 /-2.42$ \\
\hline
\end{tabular}




\section{Photophysical properties}

Figure 1 presents the absorption (Abs) and photoluminescence (PL) spectra of $\operatorname{Ir}(\mathrm{ppy})_{2} \mathrm{~L} 1$, $\operatorname{Ir}(\text { ppy })_{2} \mathrm{~L} 2$, and $\operatorname{Ir}(\text { ppy })_{2} \mathrm{~L} 3$. The solution and film spectra correspond to the acetonitrile solution and the spin-coated sample, respectively. All the complexes show a strong absorbance in the UV region $\left(<380 \mathrm{~nm}\right.$ ), which corresponds to the ligand-centered (LC) $\pi-\pi^{*}$ transitions. ${ }^{28,29}$ In the visible region, with increasing the wavelength, we assign the absorption peaks to the mechanisms of the singlet metal-to-ligand charge transfer $\left({ }^{1}\right.$ MLCT $),{ }^{28}$ the spin-orbit coupling enhanced ${ }^{3} \pi-\pi^{*}$ transition, and the spin-forbidden triplet MLCT $\left({ }^{3} \mathrm{MLCT}\right)$. A strong ${ }^{3}$ MLCT is observed due to an efficient singlet-triplet mixing, a clear signature of the $\operatorname{Ir}(\mathrm{III})$ complexes. ${ }^{30}$

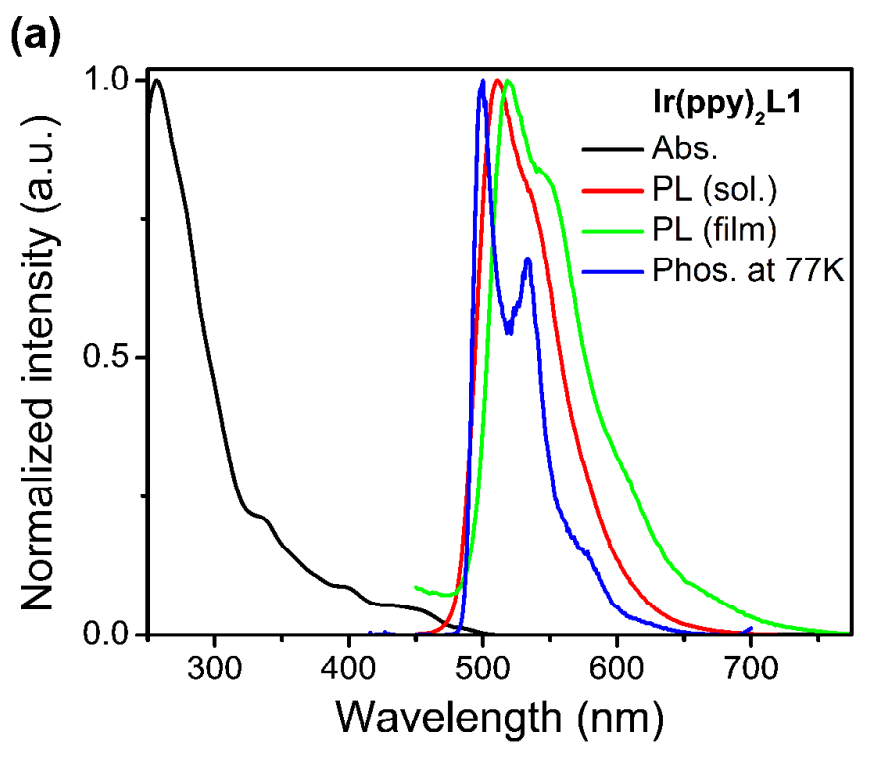


(b)

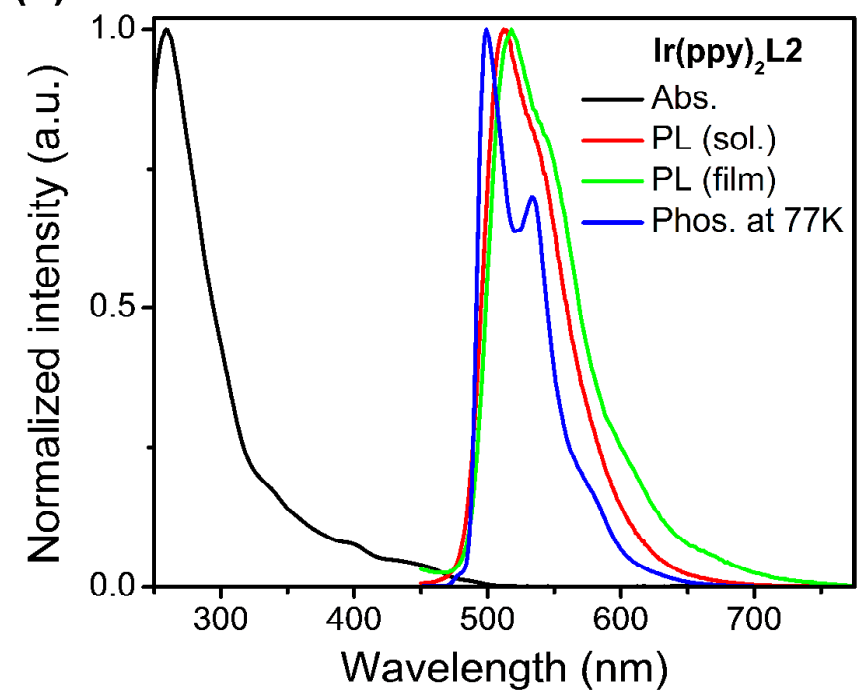

(c)

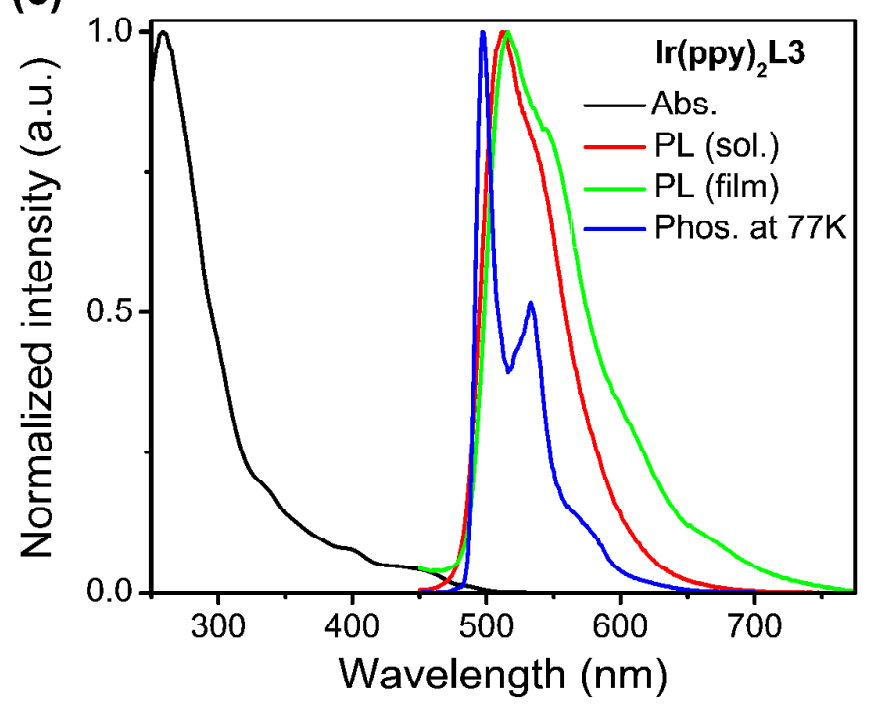

Figure 1. Absorption (Abs) spectra, photoluminescence (PL) spectra (in solution and film), and phosphorescence spectra (at 77K) of the green iridium complexes, (a) $\operatorname{Ir}(\mathrm{ppy})_{2} \mathrm{~L} 1$, (b) $\operatorname{Ir}(\mathrm{ppy})_{2} \mathrm{~L} 2$, and (c) $\operatorname{Ir}(\mathrm{ppy})_{2} \mathrm{~L} 3$.

The PL spectra are centered at $511 \mathrm{~nm}$ for $\operatorname{Ir}(\mathrm{ppy})_{2} \mathrm{~L} 1$ and $512 \mathrm{~nm}$ for $\operatorname{Ir}(\mathrm{ppy})_{2} \mathrm{~L} 2$ and $\operatorname{Ir}(\text { ppy })_{2} \mathrm{~L} 3$, and there is a small degree of bathochromic shift observed among the samples considered (see Fig. 1). It is noteworthy that all the synthesized compounds show excellent solubility in the commonly-used solvents, including acetonitrile, chloroform, dichloromethane, and toluene, as reflected by their strong and consistent PL spectra (Fig. S3), demonstrating the 
versatility and promise for solution processing. ${ }^{31}$ The PL spectra of Ir complexes in the solid state thin films show a redshift $5 \pm 1 \mathrm{~nm}$ compared to those in the solution. At a low temperature $(77 \mathrm{~K})$, the PL spectra of all the three Ir complexes show the multiple vibronic emission peaks (Fig.1).

Table 1 summarizes the $\Phi_{P L s}$ and the average exciton lifetimes $\left(\tau_{a v g}\right)$ for the synthesized compounds at different conditions. The quantum yield was determined using the relative method calibrated by the typical green phosphor, $\operatorname{Ir}(\mathrm{ppy})_{3}$, which possess a $\Phi_{P L}$ of $40 \%$ in acetonitrile. ${ }^{32,33}$ Among the three emitters synthesize, the $\Phi_{P L}$ for $\operatorname{Ir}(\mathrm{ppy})_{2} \mathrm{~L} 1$ is the highest and about two-fold higher than that for $\operatorname{Ir}(\mathrm{ppy})_{3}$. We suppose that the high $\Phi_{P L}$ results from the more rigid carbon-chlorine bond, compared to the carbon-hydrogen bond in $\operatorname{Ir}(\mathrm{ppy})_{3} .{ }^{34}$ Compared to the PL spectra at room temperature, the low-temperature ones exhibit two additional peaks, which correspond to the triplet emission, owing to an efficient intersystem crossing (ISC). ${ }^{32,35}$ The triplet-energies $\left(E_{T}\right)$ were therefore determined to be $2.48 \mathrm{eV}, 2.49 \mathrm{eV}$, and $2.50 \mathrm{eV}$ for $\operatorname{Ir}(\text { ppy })_{2} \mathrm{~L} 1, \operatorname{Ir}(\text { ppy })_{2} \mathrm{~L} 2$, and $\operatorname{Ir}(\text { ppy })_{2} \mathrm{~L} 3$, respectively. The extracted $\tau_{\text {avg }}$ of all the three emitters range between 0.117 and $0.272 \mu s$ at room temperature, and are increased up to 0.13 to $0.34 \mu s$ at $77 \mathrm{~K}$. The radiative rate constant $\left(k_{r}\right)$ and non-radiative rate constant $\left(k_{n r}\right)$ are estimated from the $\Phi_{P L}$ and $\tau_{a v g}$ by using the equations $k_{r}=\Phi_{P L} / \tau$ and $\Phi_{P L}=k_{r} /\left(k_{r}+k_{n r}\right) .{ }^{36} \operatorname{In}$ particular, $\operatorname{Ir}(\mathrm{ppy})_{2} \mathrm{~L} 1$ emitter exhibits nearly threefold increase of $\tau_{a v g}$ at $77 \mathrm{~K}$, resulting from a reduction of triplet exciton quenching. At room temperature, $\operatorname{Ir}(\mathrm{ppy})_{2} \mathrm{~L} 1$ also has a short excited state lifetime of $0.117 \mu \mathrm{s}$ that yields $k_{r}$ of $7.61 \times 10^{7} \mathrm{~s}^{-1}$ and $k_{n r}$ of $9.44 \times 10^{6} \mathrm{~s}^{-1}$ (Table 1). A slower non-radiative recombination rate leads to a strong ISC of singlet excited states that results in a high internal quantum efficiency. This fact is also reflected from the rate constants at low temperature $\left(k_{r}=\right.$ $2.62 \times 10^{6} \mathrm{~s}^{-1}$ and $k_{n r}=3.26 \times 10^{5} \mathrm{~s}^{-1}$ ). Table 1 also summarizes the extracted $k_{r}$ and $k_{n r}$ for $\operatorname{Ir}(\text { ppy })_{2} \mathrm{~L} 2$ and $\operatorname{Ir}(\text { ppy })_{2} \mathrm{~L} 3$ counterparts. On the other hand, for $\operatorname{Ir}(\text { ppy })_{2} \mathrm{~L} 2$ and $\operatorname{Ir}(\mathrm{ppy})_{2} \mathrm{~L} 3, k_{n r}$ is higher than $k_{r}$, thereby resulting in a low $\Phi_{P L}$. 


\section{Electrochemical properties}

We characterize the electrochemical properties of the Ir complexes by the cyclic voltammetry (CV) in nitrogen atmosphere at room temperature. The HOMO energy level is determined using the oxidation potential, as shown in Fig. S4. The information allows us to estimate the lowest unoccupied molecular orbital (LUMO) energy with the optical bandgap $\left(E_{g}\right)$, as determined by the room-temperature PL spectrum. Table 1 presents the calculated energy bandgaps, HOMO and LUMO levels for the complexes considered. Note that the HOMO level for $\operatorname{Ir}(\mathrm{ppy})_{2} \mathrm{~L} 1$ is about $0.2 \mathrm{eV}$ shallow relative to the other two counterparts, owing to the electron-withdrawing chlorine atom (R1, see Scheme 1) in the phenyl ring of the ancillary ligand. ${ }^{37}$ The emission spectrum of the $\operatorname{Ir}(\mathrm{III})$ complexes is dominated by the ppy ligands, whereas the effect of the ancillary ligand is negligible. The electron-withdrawing/electron-donating nature of the substituent in ancillary ligand, on the other hand, mainly affects $d$ - $\pi$ orbital hybridization of $\mathrm{Ir}$ atom and therefore changes the HOMO and LUMO energy levels. ${ }^{38}$ The oxidation potential in $\operatorname{Ir}(\text { ppy })_{2} \mathrm{~L} 1$ is about $0.1 \mathrm{eV}$ higher than that in the other two, consistent with the DFT-calculated values (Fig.2).

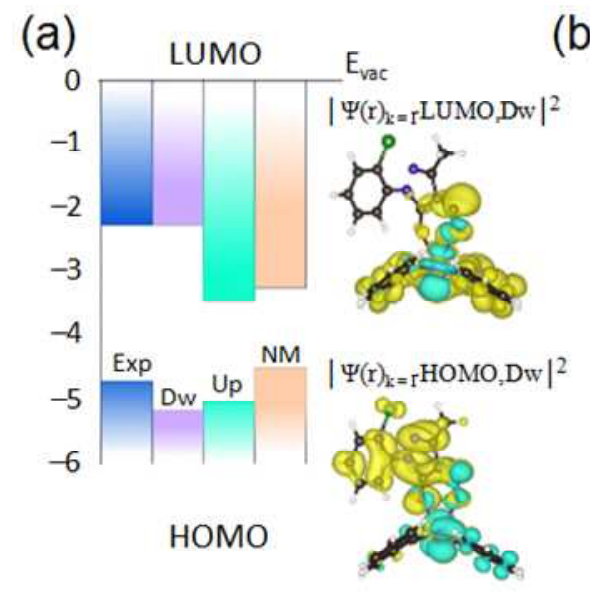

(b)

(c)
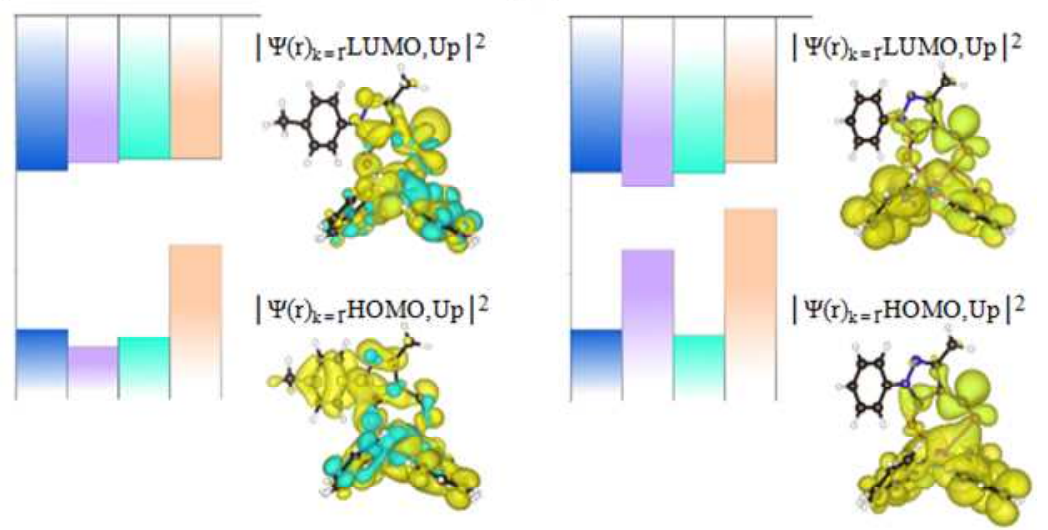

Figure 2. Hybrid HSE06 calculations for energy frontier levels (HOMO, LUMO) for (a) $\operatorname{Ir}(\text { ppy })_{2} L 1$, (b) $\operatorname{Ir}(\text { ppy })_{2} \mathrm{~L} 2$, and (c) $\operatorname{Ir}(\text { ppy })_{2} \mathrm{~L} 3$. Spin up (Up), spin down (Dw) and non-magnetic (NM) spin-solutions are shown in cyan, violet and faint brown, respectively. A comparison with 
the experimental results (Exp) in blue is included at the first column to each system. Energy states are relative to the vacuum level (Evac) at $0 \mathrm{eV}$. The spatial electron distributions (isosurface cutoff $3.1210-4 \mathrm{e} / \AA \AA 3$ ) of the HOMO and LUMO states of the closest set of calculations to the experimental results is shown aside each system. Yellow and blue isosurfaces show positive and negative charge densities, respectively.

\section{Theoretical simulation}

In order to gain a better insight into the electronic structures and photophysical characteristics of the green $\operatorname{Ir}(\mathrm{III})$ molecules, we performed first-principles density functional theory (DFT) calculations including hybrid functionals (see Methods for details). We took a fractional component of the exact exchange from the Hartree-Fock (HF) theory hybridized with the DFT exchange correlation potential at the level of the range-separated HSE06 hybrid functional. Such approach has been observed to improve the physical and chemical properties, as well as optical excitations of several compounds at a relative good balance between accuracy and timeconsuming simulations. ${ }^{39}$ Calculations have included spin-polarized effects as they were observed to be important in the analysis of the electronic properties. Fig. 2 shows the HSE06 energy frontier levels (HOMO, LUMO) for $\operatorname{Ir}(\text { ppy })_{2} \mathrm{~L} 1, \operatorname{Ir}(\mathrm{ppy})_{2} \mathrm{~L} 2$ and $\operatorname{Ir}(\text { ppy })_{2} \mathrm{~L} 3$ systems at different spin solutions. Interestingly, large variations of the position of the HOMO and LUMO energy states are observed relative to the experimental results depending on the spin-polarization included in the simulations. Non-magnetic solutions tend to underestimate the HOMO-LUMO gap for all molecules by several hundreds of meV's, with the best agreement for $\operatorname{Ir}(\mathrm{ppy})_{2} \mathrm{~L} 1$, $\operatorname{Ir}(\text { ppy })_{2} \mathrm{~L} 2$ and $\operatorname{Ir}(\text { ppy })_{2} \mathrm{~L} 3$ on spin down, spin up and spin up polarizations, respectively. These magnetic solutions are also more energetically stable than the non-magnetic ones, with energy well above room temperature in the range of $0.815 \mathrm{eV}$ to $0.356 \mathrm{eV}$ per molecular unit (see Table 2). A magnetic moment of $1.0 \mu_{\mathrm{B}}$ per unit cell is developed at each $\operatorname{Ir}(\mathrm{III})$ complex. The charge density plots for the HOMO and LUMO states also show the distribution of the orbitals at 
different parts of the Ir(III) complexes. They tend to be spread out over the entire molecule at the HOMO level but with less contribution at the radical side at the LUMO state where the different binding groups take place, e.g. chloro and methyl (Fig. 2). Such inhomogeneous charge distribution induces the appearance of dipole moments as large as 6.56 Debye for $\operatorname{Ir}(\mathrm{ppy})_{2} \mathrm{~L} 1$ (Table 2). The Bader analysis plotted in Fig. 3 show that most of the atoms nearby Ir gain charge, which includes $\mathrm{O}$ and $\mathrm{N}$ atoms. This suggests that the charge balance between $\mathrm{Ir}$ and its near neighbors induce the appearance of the dipole moment in the molecule. This is agreement with recent angle-dependent photoluminescence measurements for similar $\operatorname{Ir}(\mathrm{III})$ complexes. ${ }^{40}$ We have also simulated the optical properties for all three molecules as shown in Fig. S5. The highest absorption peaks in the experimental results at $298 \mathrm{~nm}, 260 \mathrm{~nm}$ and $259 \mathrm{~nm}$ for $\operatorname{Ir}(\text { ppy })_{2} \mathrm{~L} 1, \operatorname{Ir}(\text { ppy })_{2} \mathrm{~L} 2$ and $\operatorname{Ir}(\text { ppy })_{2} \mathrm{~L} 3$, respectively, can be well described by the $\mathrm{x}$-component of the absorption spectra. These peaks correspond to an excitation in the ultraviolet of $4.37 \mathrm{eV}$ $\left(\operatorname{Ir}(\mathrm{ppy})_{2} \mathrm{~L} 1\right), 4.35 \mathrm{eV}\left(\operatorname{Ir}(\mathrm{ppy})_{2} \mathrm{~L} 2\right)$ and $4.64 \mathrm{eV}\left(\operatorname{Ir}(\mathrm{ppy})_{2} \mathrm{~L} 3\right)$, which also have large dipole transition elements (see Tables S1-S3 in SI).

(a)

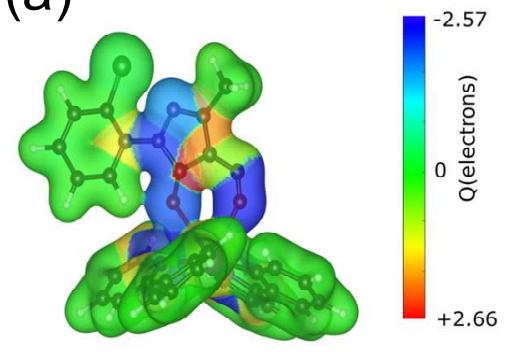

(b)

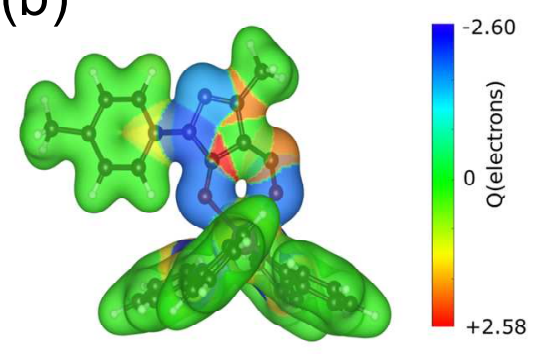

(C)

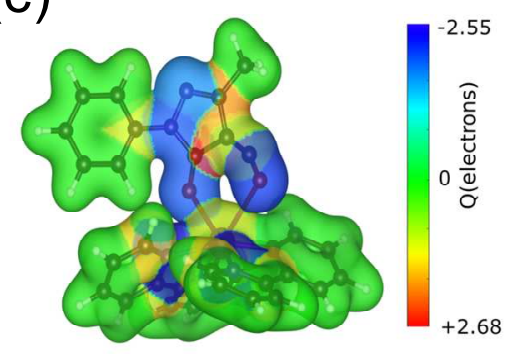

Figure 3. Isosurfaces of the Bader analysis performed for (a) $\operatorname{Ir}(p p y)_{2} L 1$, (b) $\operatorname{Ir}(p p y)_{2} L 2$, and (c) $\operatorname{Ir}(\text { ppy })_{2}$ L3 at HSE06 hybrid level. The gradient scale shows the variation of the Bader charge, $\mathrm{Q}($ electrons), for specific atoms in the oligomers. Positive (negative) magnitudes of Q(electrons) show charge depletion (accumulation). Notice that $\mathrm{O}$ (red) and $\mathrm{N}$ atoms (blue) gain charge, while Ir atoms loose.

Table 2. Calculated magnetic energies $\Delta \mathrm{E}$ through the energy difference between spin-polarized and non-spin-polarized calculations and magnitudes of the electric dipole moment (Debye) at 
HSE06 hybrid level and for $\operatorname{Ir}(\text { ppy })_{2} \mathrm{~L} 1, \operatorname{Ir}(\text { ppy })_{2} \mathrm{~L} 2$, and $\operatorname{Ir}(\mathrm{ppy})_{2} \mathrm{~L} 3$. Non-magnetic (NM) and spin-polarized (SP) simulations are shown per unit cell.

\begin{tabular}{|c|c|c|c|}
\hline \multirow[t]{2}{*}{ Molecule } & \multirow{2}{*}{$\Delta E(e V)$} & \multicolumn{2}{|c|}{ Dipole Moment (Debye) } \\
\hline & & NM & SP \\
\hline $\operatorname{Ir}(\mathrm{ppy})_{2} \mathrm{~L} 1$ & -0.815 & 5.535 & 6.564 \\
\hline $\operatorname{Ir}(\text { ppy })_{2} \mathrm{~L} 2$ & -0.714 & 6.357 & 6.073 \\
\hline $\operatorname{Ir}(\text { ppy })_{2} \mathrm{~L} 3$ & -0.356 & 4.433 & 4.977 \\
\hline
\end{tabular}

Table 3. Effect of Ir complexes on the fabrication process, operating voltage (OV), power efficiency $\left(\eta_{\mathrm{PE}}\right)$, current efficiency $\left(\eta_{\mathrm{CE}}\right)$, EQE ( $\left.\eta_{\mathrm{EQE}}\right)$, CIE color coordinates and maximum luminance by doping the various concentrations in the CBP host.

\begin{tabular}{|c|c|c|c|c|c|c|c|c|}
\hline \multirow[t]{2}{*}{ Emitter } & \multirow[t]{2}{*}{ Process } & \multirow{2}{*}{$\begin{array}{c}\text { wt \% of } \\
\text { emitter in } \\
\text { CBP host }\end{array}$} & $\begin{array}{l}\text { OV } \\
(\mathrm{V})\end{array}$ & $\begin{array}{l}\eta_{\mathrm{PE}} \\
(\mathrm{Im} / \mathrm{W}) \\
\end{array}$ & $\begin{array}{l}\eta_{\mathrm{CE}} \\
(\mathbf{c d} / \mathbf{A}) \\
\end{array}$ & $\begin{array}{l}\eta_{\mathrm{EQE}} \\
(\%)\end{array}$ & \multirow{2}{*}{$\begin{array}{l}\mathbf{C I E}_{\mathbf{x}, \mathbf{y}} \\
\text { Coordinates }\end{array}$} & \multirow{2}{*}{$\begin{array}{l}\text { Maximum } \\
\text { luminance } \\
\left(\mathbf{c d} / \mathbf{m}^{2}\right)\end{array}$} \\
\hline & & & \multicolumn{4}{|c|}{ @ $100 / 1,000 \mathrm{~cd} / \mathrm{m}^{2}$} & & \\
\hline \multirow[t]{6}{*}{$\operatorname{Ir}(\text { ppy })_{2} \mathrm{~L} 1$} & & 5 & $4.1 / 5.2$ & $29.6 / 19.6$ & $38.9 / 32.3$ & $10.3 / 9.0$ & $(0.28,0.63)$ & 11990 \\
\hline & Solution & 10 & $4.1 / 5.0$ & $30.3 / 29.2$ & $39.6 / 46.4$ & $10.7 / 12.6$ & $(0.29,0.63)$ & 10380 \\
\hline & & 15 & $4.1 / 5.0$ & $28.5 / 26.0$ & $37.3 / 41.7$ & $10.1 / 11.3$ & $(0.29,0.63)$ & 10810 \\
\hline & & 5 & $4.1 / 5.1$ & $31.3 / 26.6$ & $41.0 / 42.6$ & $10.5 / 11.5$ & $(0.30,0.63)$ & 15270 \\
\hline & Dry & 10 & $4.2 / 5.5$ & $47.7 / 31.0$ & $63.7 / 54.7$ & $17.4 / 15.2$ & $(0.31,0.63)$ & 20970 \\
\hline & & 15 & $4.2 / 5.5$ & $40.2 / 26.0$ & $54.2 / 46.5$ & $14.8 / 12.7$ & $(0.31,0.63)$ & 20580 \\
\hline \multirow[t]{3}{*}{$\operatorname{Ir}(\text { ppy })_{2} \mathrm{~L} 2$} & & 5 & $4.5 / 5.6$ & $11.6 / 10.4$ & $16.7 / 18.4$ & $4.6 / 5.1$ & $(0.29,0.63)$ & 7824 \\
\hline & Solution & 10 & $4.7 / 5.9$ & $11.1 / 9.1$ & $16.4 / 17.1$ & $3.7 / 4.5$ & $(0.29,0.63)$ & 7615 \\
\hline & & 15 & $4.7 / 6.1$ & $8.7 / 6.9$ & $13.1 / 13.4$ & $3.2 / 3.5$ & $(0.30,0.63)$ & 6328 \\
\hline \multirow[t]{3}{*}{$\operatorname{Ir}(\text { ppy })_{2} \mathrm{~L} 3$} & & 5 & $5.0 / 5.8$ & $6.4 / 10.4$ & $10.2 / 19.0$ & $3.1 / 5.9$ & $(0.26,0.55)$ & 10700 \\
\hline & Solution & 10 & $5.5 / 6.6$ & $3.6 / 9.3$ & $6.4 / 19.5$ & $1.8 / 5.6$ & $(0.29,0.61)$ & 12130 \\
\hline & & 15 & $5.3 / 6.6$ & $2.6 / 6.5$ & $4.5 / 13.6$ & $1.3 / 3.8$ & $(0.29,0.62)$ & 10130 \\
\hline
\end{tabular}

\section{Electroluminescent characteristics}

The OLEDs based on the new Ir(III) complexes were fabricated and characterized. Fig. 4a presents the device architectures and energy levels used in the solution-processed samples. The current density-voltage-luminance $(J-V-L)$ characteristics, together with the calculated $\eta_{C E}$ and $\eta_{P E}$ as a function of $L$, are shown in Figs. $\mathbf{4 b}, \mathbf{4 c}$, and $\mathbf{4 d}$, respectively. The solution-processed sample of $\operatorname{Ir}(\text { ppy })_{2} \mathrm{~L} 1$, with an architecture of ITO/PEDOT:PSS/EML $\left(5 \mathrm{wt} \% \operatorname{Ir}(\mathrm{ppy})_{2} \mathrm{~L} 1+\right.$ 
$\mathrm{CBP} / \mathrm{TPBi} / \mathrm{LiF} / \mathrm{Al}$, show $\eta_{C E}$ of $32.3 \mathrm{~cd} \mathrm{~A}^{-1}$ and $\eta_{\mathrm{PE}}$ of $19.61 \mathrm{~m} \mathrm{~W}^{-1}$ at $1000 \mathrm{~cd} \mathrm{~m}^{-2}$, and by increasing the weight concentration to $10 \mathrm{wt} \%$, which is determined to be the optimal concentration, a considerable degree of enhancement in efficiencies is achieved ( $\eta_{C E}=46.4 \mathrm{~cd}$ $\mathrm{A}^{-1}$ and $\eta_{\mathrm{PE}}$ of $29.21 \mathrm{~m} \mathrm{~W}^{-1}$ ). The device performance is slightly reduced by further increasing the concentration, probably due to a more significant degree of self-quenching.

(a)

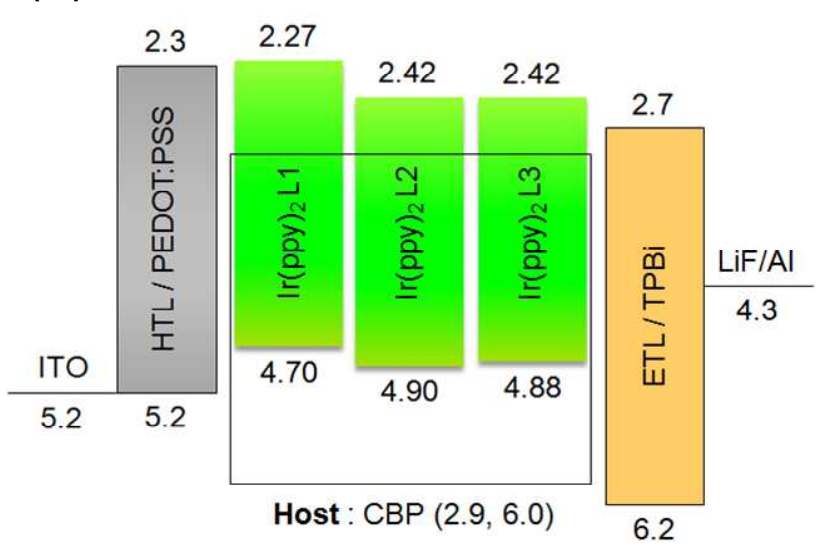

(b)

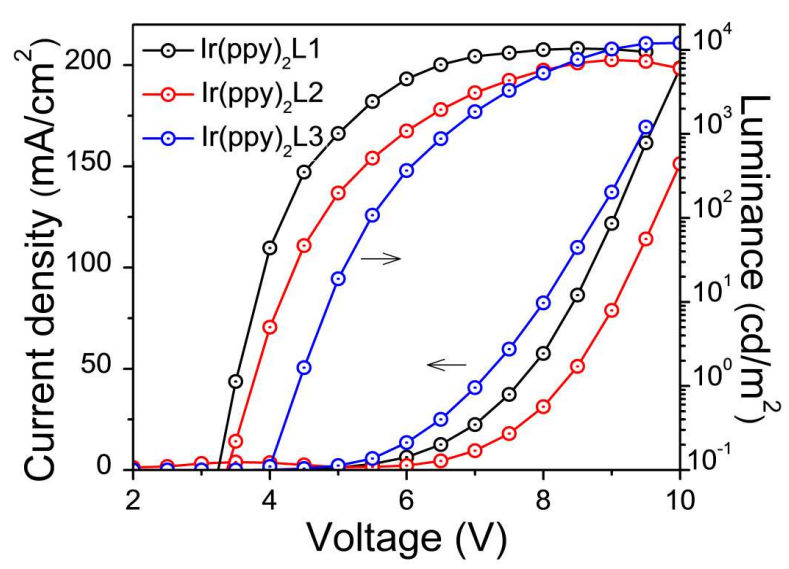

(c)

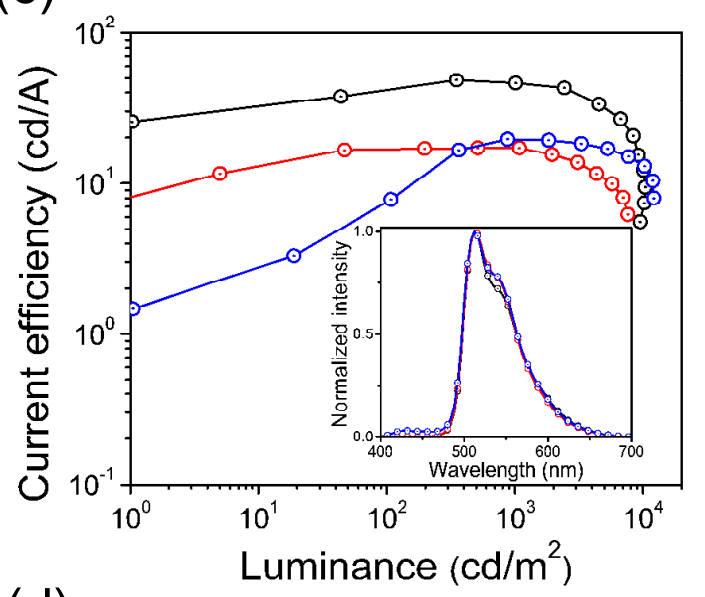

(d)

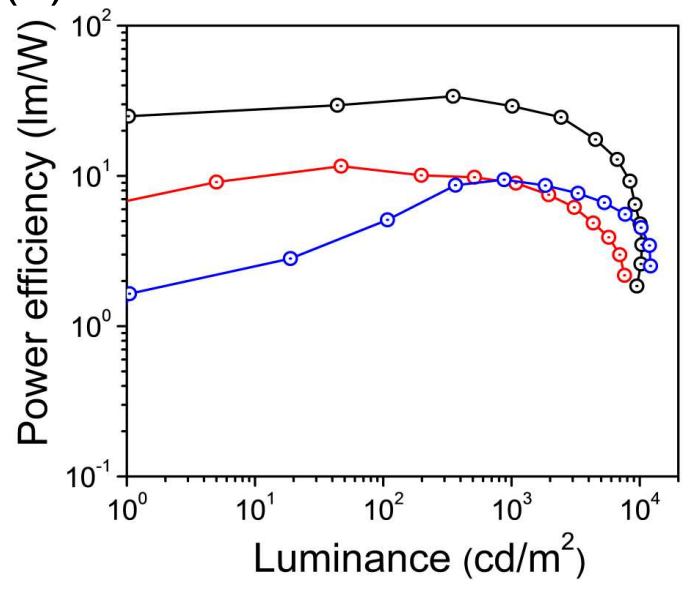

Figure 4. Solution-process OLEDs based on $10 \mathrm{wt} \%$ Ir complexes in the CBP host. (a) Schematic energy-levels diagram, (b) $J-V-L$ characteristics, (c) current efficiency as a function of luminance, Inset: electroluminescence spectra (d) power efficiency as a function of luminance. 
The device characteristics for the solution-processed $\operatorname{Ir}(\mathrm{ppy})_{2} \mathrm{~L} 1, \operatorname{Ir}(\mathrm{ppy})_{2} \mathrm{~L} 2$, and $\operatorname{Ir}(\text { ppy })_{2} \mathrm{~L} 3$ at different concnetrations are summarized in Table 3. Clearly, $\operatorname{Ir}(\mathrm{ppy})_{2} \mathrm{~L} 1$ is the best emitter among the three compounds considered here. In combination with the photophysical characteristics determined earlier, we attribute the superior performance to the following mechanisms: (i) a high $\Phi_{P L}$ of $89 \%$, (ii) a proper exciton lifetime that allows effective ISC and prevents triplet quenching, and (iii) a high radiative rate constant that implies an efficient triplet metal to ligand charge transfer $\left({ }^{3} \mathrm{MLCT}\right)$ and triplet ligand-centered transition $\left({ }^{3} \mathrm{LC}\right)$. All three devices showed EL emission at $512 \mathrm{~nm}$, which is consistent with the PL of $\operatorname{Ir}(\mathrm{ppy})_{2} \mathrm{~L} 1$, $\operatorname{Ir}(\text { ppy })_{2}$ L2, and $\operatorname{Ir}(\text { ppy })_{2}$ L3 (see inset Fig. 4c).

(a)

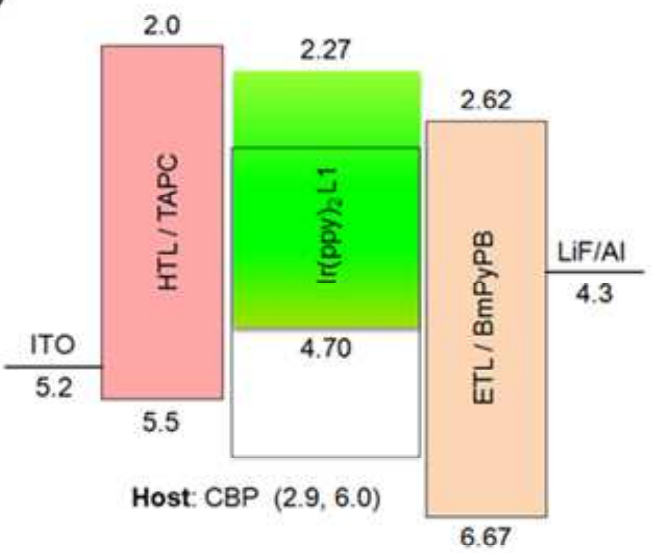

(c)

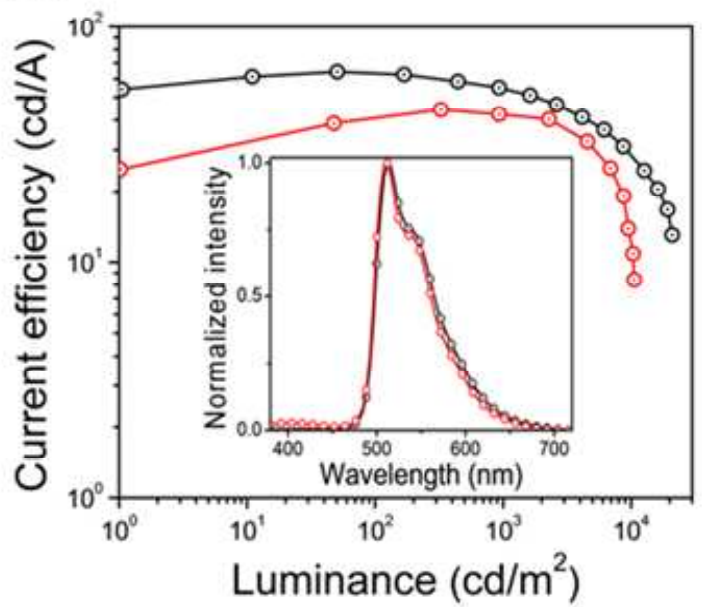

(b)

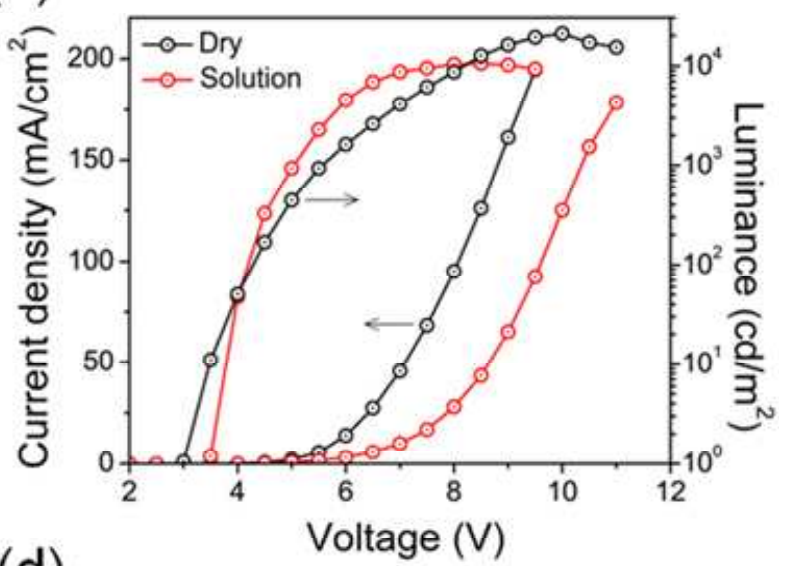

(d)

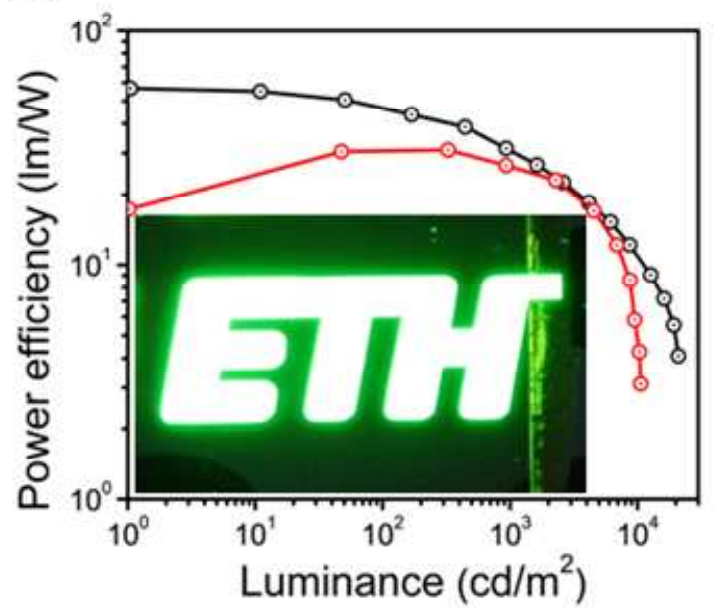


Figure 5. Comparison of dry- and solution-processed OLED devices based on $\operatorname{Ir}(\mathrm{ppy})_{2} \mathrm{~L} 1$ emitter. (a) Schematic energy-levels diagram of dry-processed device. (b) $J-V-L$ characteristics, (c) current efficiencies as a function of luminance, Inset: normalized EL spectra. (d) power efficiencies as a function of luminance, Inset: large area ETH logo device operating at $5 \mathrm{~V}$ (active area $\sim 2 \mathrm{~cm}^{2}$ ).

The outstanding performance of the $\operatorname{Ir}(\mathrm{ppy})_{2} \mathrm{~L} 1$ based solution-processed devices encourages us to test the dry-processed samples. Fig. 5a shows the device architecture considered and the energy levels, with a typical trilayer structure comprised of a $30 \mathrm{~nm}$ di-[4- $(N$, $N$-ditolyl-amino)-phenyl]cyclohexane (TAPC) as HTL, a $25 \mathrm{~nm}$ EML containing $\operatorname{Ir}(\mathrm{ppy})_{2} \mathrm{~L} 1$ in CBP with a controlled concentration $(5,10$, and $15 \mathrm{wt} \%)$, and a $35 \mathrm{~nm}$ 1,3-bis(3,5-dipyrid-3-ylphenyl)benzene (BmPyPB) ETL. The $J-V-L$ characteristics are shown in Fig. 5 b and Table 3. The EL spectrum for the dry-processed device is consistent with that for the solution-processed one. In addition to the fact that high $\eta_{C E}$ of $63.7 \mathrm{~cd} \mathrm{~A}^{-1}$ and $\eta_{\mathrm{PE}}$ of $47.7 \mathrm{~lm} \mathrm{~W}^{-1}$ are achieved at $100 \mathrm{~cd} \mathrm{~m}^{-2}$, in particular, the device shows only a $16 \%$ roll-off in $\eta_{C E}$ at $1000 \mathrm{~cd} \mathrm{~m}^{-2}$. The dryprocessed device show $61 \%, 58 \%$, and $63 \%$ higher in $\eta_{C E}, \eta_{P E}$, and $\eta_{E Q E}$, respectively, compared to the solution-processed counterparts (Fig. 5c and 5d). We attribute the enhanced device performance to: (i) a high hole mobility in the TAPC HTL, (ii) a high LUMO level (-2.0 eV) in the TAPC HTL that results in an efficient electron confinement, ${ }^{41,42}$ (iii) a high electron mobility in the BmPyPB ETL, and (iv) a deep HOMO level in the BmPyPB layer that results in an efficient hole confinement. ${ }^{3}$ In addition, as shown in Fig. 5b, the dry-processed device shows a nearly two-fold increase in $L_{\max }$ relative to that in the solution-processed OLED device. Both devices demonstrate an identical EL emission at 512 nm (inset: Fig. 5c).

Figure S6 shows the operational lifetime $\left(t_{50}\right)$, referring to the duration before the luminance drops to $50 \%$ of the initial value, in the OLED devices using $\operatorname{Ir}(\mathrm{ppy})_{2} \mathrm{~L} 1$ and conventional $\operatorname{Ir}(\text { ppy })_{3}$. The $\operatorname{Ir}(\text { ppy })_{2}$ L1-based device (ITO/PEDOT:PSS/TAPC/EML $\left(\operatorname{Ir}(\text { ppy })_{2}\right.$ L1 
$+\mathrm{CBP}) / \mathrm{BmPyPB} / \mathrm{LiF} / \mathrm{Al})$ shows a $t_{50}$ value of 2.5 hours with an initial luminance $\left(L_{0}\right)$ of 1097 $\mathrm{cd} \mathrm{m}^{-2}$. On the other hand, the $\operatorname{Ir}(\mathrm{ppy})_{3}$ device was tested at a higher $L_{0}\left(t_{50}=1.46\right.$ hours at $L_{0}$ of $1754 \mathrm{~cd} \mathrm{~m}^{-2}$ ). We extrapolate and estimate the $t_{50}$ values at $L_{0}=100 \mathrm{~cd} \mathrm{~m}^{-2}$ to be 146.5 hours and 190.2 hours, for $\operatorname{Ir}(\mathrm{ppy})_{2} \mathrm{~L} 1$ and $\operatorname{Ir}(\mathrm{ppy})_{3}$ devices, respectively. The performance of electrical stability is comparable.

\section{Conclusion}

In summary, we synthesize new heteroleptic $\operatorname{Ir}(\mathrm{III})$ complexes, $\operatorname{Ir}(\text { ppy })_{2} \mathrm{~L} 1, \operatorname{Ir}(\text { ppy })_{2} \mathrm{~L} 2$, and $\operatorname{Ir}(\text { ppy })_{2} \mathrm{~L} 3$ by introducing new ancillary ligands. In particular, the complex based on the 1-(2chlorophenyl)-5-hydroxy-3-methyl-1H-pyrazole-4-carbaldehyde (L1) ligand, shows a high $\Phi_{P L}$ of $89 \%$ in solution and excellent solubility in the commonly-used polar solvents. We demonstrate its solution- and dry-processed light emitting devices, with highest current efficiencies of $46 \mathrm{~cd} \mathrm{~A}^{-1}$ and $64 \mathrm{~cd} \mathrm{~A}^{-1}$, respectively. We believe that with further optimization in device architecture, $\operatorname{Ir}(\mathrm{ppy})_{2} \mathrm{~L} 1$ would be a promising candidate for the efficient phosphorescent OLED devices.

\section{Experimental}

\section{Materials and Characterizations}

Iridium (III) chloride hydrate, 2-phenyl pyridine and 2-ethoxyethanol (Sigma-Aldrich), 1phenyl-3-methyl-2-pyrazoline-5-one (Merck) were used as received. The organic solvents and other reagents were used after purification using the standard protocols. ${ }^{43,}{ }^{44}$ All the reactions were carried out in nitrogen atmosphere with the Schlenk line. The nuclear magnetic resonance (NMR) spectra were collected using a Bruker 400 MHz Spectrometer (Fig. S7-S9). Deuterated 
dimethyl sulfoxide (DMSO- $\mathrm{d}_{6}$ ) was used as solvent for the measurement and calibration for the residual peak of the deuterated solvent ( $\delta 2.52$ for ${ }^{1} \mathrm{H}$ NMR). The high resolution mass spectra (HR-MS) of the complexes were taken with the Shimadzu LCMS-2010 Spectrometer (Fig. S10). The FT-IR Spectra were taken with the Infrared Spectrophotometer MB-3000 (Fig. S11).

Synthesis of Ir(ppy) ${ }_{2} \boldsymbol{L 1}$ : A mixture of $\operatorname{IrCl}_{3} \cdot 3 \mathrm{H}_{2} \mathrm{O}(0.35 \mathrm{~g}, 1 \mathrm{mmol})$ and ppy $(0.4 \mathrm{~g}, 2.20 \mathrm{mmol})$ in a mixture of 2-ethoxyethanol and water $(20 \mathrm{~mL}, 3: 1, \mathrm{v} / \mathrm{v})$ was refluxed under nitrogen for 48 h. The reaction mixture was then cooled down to room temperature and water $(10 \mathrm{~mL})$ was added. The mixture was filtered and the residue was washed with water $(20 \mathrm{~mL})$ and ethanol $(20$ $\mathrm{mL})$. The crude dichloro-bridged diiridium complex $(0.57 \mathrm{~g}),\left[\operatorname{Ir}(\mathrm{ppy})_{2} \mathrm{Cl}\right]_{2}$, was collected without further purification after it was dried out. A solution of ligand 1-(2-chlorophenyl)-5hydroxy-3-methyl-1H-pyrazole-4-carbaldehyde (L1) $(0.1 \mathrm{~g}, 0.4 \mathrm{mmol})$ and the dichloro-bridged diiridium complex $\left[\operatorname{Ir}(\mathrm{ppy})_{2} \mathrm{Cl}\right]_{2}(0.21 \mathrm{~g}, 0.2 \mathrm{mmol})$ in 2-ethoxyethanol $(20 \mathrm{~mL})$ was refluxed in the presence of $\mathrm{Na}_{2} \mathrm{CO}_{3}$ under nitrogen for $24 \mathrm{~h}$ in dark. After cooling to room temperature, the mixture was precipitated while stirring. The precipitate of complex $\mathbf{1}$ was filtered and washed with ethanol $(20 \mathrm{~mL})$ as an eluent: yellow solid; yield $(0.19 \mathrm{~g}, 68 \%)$.

Spectral data: IR $\left(\mathrm{KBr}\right.$ pellet $\left.\mathrm{cm}^{-1}\right) 1620(-\mathrm{HC}=\mathrm{O}) ;{ }^{1} \mathrm{H}$ NMR $\left(400 \mathrm{MHz}, \mathrm{d}_{6}-\mathrm{DMSO}, \delta[\mathrm{ppm}]\right)$ : $8.90(\mathrm{~s}, 1 \mathrm{H},-\mathrm{CHO}), 8.55$ (d, J=4.4 Hz, 1H), 8.41 (d, J=6.8 Hz, 1H), 8.18-8.12 (m, 2H), 7.98-7.93 (m, 2H), $7.71(\mathrm{~d}, J=6.8 \mathrm{~Hz}, 1 \mathrm{H}), 7.65(\mathrm{~d}, J=7.2 \mathrm{~Hz}, 1 \mathrm{H}), 7.41-7.31(\mathrm{~m}, 6 \mathrm{H}), 6.83-6.52(\mathrm{~m}, 4 \mathrm{H})$, $6.12(\mathrm{~d}, J=6.8 \mathrm{~Hz}, 1 \mathrm{H}), 5.98(\mathrm{~d}, J=6.8 \mathrm{~Hz}, 1 \mathrm{H}), 2.19\left(\mathrm{~s}, 3 \mathrm{H},-\mathrm{CH}_{3}\right) ;{ }^{13} \mathrm{C} \mathrm{NMR}(\mathrm{APT})(100 \mathrm{MHz}$, DMSO, $\delta): 179.47,167.83,154.43,150.46,148.74,148.46,145.76,145.49,144.60,144.40$, $144.17,138.89,138.55,133.44,132.87,131.06,130.37,130.23,130.16,129.01,128.88,128.26$, $124.43,123.17,123.06,121.46,121.19,119.50,119.50,119.41,106.95,13.31$. HR-MS calcd for 
$\mathrm{C}_{33} \mathrm{H}_{24} \mathrm{O}_{2} \mathrm{~N}_{4}{ }^{193} \mathrm{IrCl}[\mathrm{M}+\mathrm{H}]^{+} \mathrm{m} / z$ 736.14, found 736.91; Anal. calcd. for $\mathrm{C}_{33} \mathrm{H}_{24} \mathrm{ClIrN}_{4} \mathrm{O}_{2}$ : C 53.83, H 3.29, N 7.61; found: C 53.14, H 3.22, N 7.85.

Synthesis of [Ir(ppy) $)_{2}$ L2]: The synthesis of $\operatorname{Ir}(\mathrm{ppy})_{2} \mathrm{~L} 2$ was similar to that of $\operatorname{Ir}(\mathrm{ppy})_{2} \mathrm{~L} 1$ except that the ancillary ligand L1 was replaced by 5-hydroxy-3-methyl-1-(p-tolyl)-1H-pyrazole-4carbaldehyde (L2). The $\operatorname{Ir}(\mathrm{ppy})_{2} \mathrm{~L} 2$ as an eluent: yellow solid; in yield $(0.18 \mathrm{~g}, 63 \%)$.

Spectral data: IR $\left(\mathrm{KBr}\right.$ pellet $\left.\mathrm{cm}^{-1}\right) 1624(-\mathrm{HC}=\mathrm{O}) ;{ }^{1} \mathrm{H}$ NMR $\left(400 \mathrm{MHz}, \mathrm{d}_{6}-\mathrm{DMSO}, \delta[\mathrm{ppm}]\right)$ : 8.89 (s, 1H, -CHO), 8.55 (d, J=5.2 Hz, 1H), 8.43 (d, J=5.2 Hz, 1H), 8.17 (t, J=6.8 Hz, 2H), 7.96 (d, $J=7.2 \mathrm{~Hz}, 1 \mathrm{H}), 7.92(\mathrm{~d}, J=8 \mathrm{~Hz}, 1 \mathrm{H}), 7.53$ (d, $J=8 \mathrm{~Hz}, 2 \mathrm{H}), 7.43-7.34(\mathrm{~m}, 4 \mathrm{H}), 7.01(\mathrm{~d}, J=8$ $\mathrm{Hz}, 2 \mathrm{H}), 6.81(\mathrm{t}, J=7.6,2 \mathrm{H}), 6.67$ (d, $J=4 \mathrm{~Hz}, 2 \mathrm{H}), 6.13(\mathrm{~d}, J=7.6 \mathrm{~Hz}, 2 \mathrm{H}), 2.21\left(\mathrm{~s}, 3 \mathrm{H},-\mathrm{CH}_{3}\right)$, $2.19\left(\mathrm{~s}, 3 \mathrm{H},-\mathrm{CH}_{3}\right) \cdot{ }^{13} \mathrm{C} \mathrm{NMR}(\mathrm{APT})(100 \mathrm{MHz}, \mathrm{DMSO}, \delta): 179.51,167.89,167.72,159.96$, $150.29,148.55,148.27,145.80,145.32,144.41,144.20,144.35,138.88,138.72,136.75,134.18$ $133.37,129.54,128.99,124.49,124.41,123.40,132.22,121.46,121.36,119.51,119.42,108.12$ 20.79, 13.26; $\mathrm{HR}-\mathrm{MS}$ calcd for $\mathrm{C}_{34} \mathrm{H}_{27} \mathrm{O}_{2} \mathrm{~N}_{4}{ }^{193} \mathrm{Ir}[\mathrm{M}+\mathrm{H}]^{+} m / z$ 716.14, found 716.97; Anal. calcd for $\mathrm{C}_{34} \mathrm{H}_{27} \mathrm{IrN}_{4} \mathrm{O}_{2}$ : C 57.05, H 3.80, N 7.83; found: C 56.67, H 3.50, N 7.91.

Synthesis of [Ir(ppy) $)_{2}$ L3]: The synthesis of $\operatorname{Ir}(\mathrm{ppy})_{2} \mathrm{~L} 3$ was similar to that of $\operatorname{Ir}(\mathrm{ppy})_{2} \mathrm{~L} 1$ except that the ancillary ligand $\mathbf{L 1}$ was replaced by 5-hydroxy-3-methyl-1-phenyl-1H-pyrazole-4carbaldehyde (L3). The $\operatorname{Ir}(\text { ppy })_{2} \mathrm{~L} 3$ as an eluent: yellow solid; yield $(0.18 \mathrm{~g}, 64 \%)$.

Spectral data: IR (KBr pellet $\left.\mathrm{cm}^{-1}\right) 1624(-\mathrm{HC}=\mathrm{O}) ;{ }^{1} \mathrm{H}$ NMR (400 MHz, $\left.\mathrm{d}_{6}-\mathrm{DMSO}, \delta[\mathrm{ppm}]\right)$ : $8.91(\mathrm{~s}, 1 \mathrm{H},-\mathrm{CHO}), 8.57(\mathrm{~d}, J=5.2 \mathrm{~Hz}, 1 \mathrm{H}), 8.44(\mathrm{~d}, J=5.2 \mathrm{~Hz}, 1 \mathrm{H}), 8.17(\mathrm{t}, J=6.6,2 \mathrm{H}), 7.97-$ $7.91(\mathrm{~m}, 2 \mathrm{H}), 7.73(\mathrm{~d}, J=7.6 \mathrm{~Hz}, 2 \mathrm{H}), 7.67$ (d, $J=8 \mathrm{~Hz}, 2 \mathrm{H}), 7.39$ (m, 2H), 7.22 (t, J=7.8 Hz, 2H), $7.06(\mathrm{t}, J=7.4 \mathrm{~Hz}, 1 \mathrm{H}), 6.82(\mathrm{t}, J=7.4 \mathrm{~Hz}, 2 \mathrm{H}), 6.66(\mathrm{~m}, 2 \mathrm{H}), 6.14(\mathrm{t}, J=7.8 \mathrm{~Hz}, 2 \mathrm{H}), 2.23$ (s, 3H, $\left.\mathrm{CH}_{3}\right) ;{ }^{13} \mathrm{C} \mathrm{NMR}(\mathrm{APT})(100 \mathrm{MHz}, \mathrm{DMSO}, \delta): 179.69,167.84,167.70,160.18,150.59,148.56$, $148.30,145.78,145.32,144.27,144.22,139.16,138.91,138.76,133.33,132.85,129.17,129.03$, 
124.97, 124.49, 123.45, 123.25, 121.50, 121.40, 119.56, 119.31 108.15, 13.30.; HR-MS calcd for $\mathrm{C}_{33} \mathrm{H}_{25} \mathrm{O}_{2} \mathrm{~N}_{4}{ }^{193} \mathrm{Ir}[\mathrm{M}+\mathrm{H}]^{+} m / z$ 702.16; found 702.97.; Anal. calcd for $\mathrm{C}_{33} \mathrm{H}_{25} \mathrm{IrN}_{4} \mathrm{O}_{2}$ : $\mathrm{C} 56.48, \mathrm{H}$ 3.59, N 7.98; found: C 56.14, H 3.36, N 8.01.

\section{Characterizations}

The ultraviolet-visible (UV-vis) absorption spectra were taken using the JASCO V670 spectrometer. The photoluminescence (PL) spectra were recorded using the Horiba Fluorolog 3 spectrometer with a Xe lamp as the excitation source. The phosphorescence spectra of Ir complexes were also recorded using Horiba Fluorolog 3 spectrometer equipped with liquid nitrogen dewar assembly. The exciton lifetime of $\operatorname{Ir}(\mathrm{III})$ complexes were measured using a timecorrelated single photon counting (TCSPC) setup, equipped with a SPC-130-EM counting module (Becker \& Hickl GmbH) and an IDQ-ID-100-20-ULN avalanche photodiode (Quantique) for recording the decay traces. The emission of the films was excited by a $355 \mathrm{~nm}$ (frequency-tripled emission of Nd:YAG laser Duetto Time-Bandwidth Products) laser pulses with a repetition of $72 \mathrm{kHz}$ triggering TCSPC counting module through an electronic delay generator (DG535 from Stanford Research Systems). The emission was filtered out from scattered laser light by long-pass filter at $400 \mathrm{~nm}$. The cyclic voltammograms (CVs) were collected on a CHI660E electrochemical workstation. The thermal behavior of Ir(III) complexes were characterized using Mettler-Toledo DSC822e differential scanning calorimeter (DSC) in the range of $100-300{ }^{\circ} \mathrm{C}$ and Mettler-Toledo thermogravimetric analyzer (TGA/SDTA 851) in the range of $50-600{ }^{\circ} \mathrm{C}$ at heating rate of $10^{\circ} \mathrm{C} \mathrm{min}^{-1}$ under nitrogen atmosphere.

\section{Theoretical Methods}

Theoretical calculations were performed using the DFT formalism as implemented in the Vienna ab initio simulation package (VASP) ${ }^{45}$ and Castep. ${ }^{46}$ For all systems a $25 \AA \times 25 \AA \times 25 \AA$ box 
was used to ensure a vacuum gap of at least $10 \AA$ in all directions. A grid of $1 \times 1 \times 1 \mathrm{k}$-sampling was used in all calculations. The three systems were optimized in CASTEP using a 500 eV plane wave energy cutoff in a spin polarised calculation using the Perdew-Burke-Ernzerhof (PBE) ${ }^{47}$ functional and pseudopotentials from the inbuilt C9 pseudopotential library. Once the initial optimization was completed the novel ligand (L1, L2 or L3 dependent on the system) was rotated with respect to the rest of the molecule, which was kept fixed, in order to find the most stable geometry. This was done in $10^{\circ}$ intervals. The lowest energy configurations from these were further optimized until all forces were less than $0.01 \mathrm{eV} / \AA$ to generate the final structures. The convergence tolerance for total energy used in these calculations was $1 \times 10^{-5} \mathrm{eV} /$ atom. The Broyden-Fletcher-Goldfarb-Shanno (BFGS) algorithm was used to perform the optimizations. ${ }^{48}$ The final geometries from this process were transferred to VASP. These calculations used PAW pseudopotentials $^{49,50}$ and a cutoff energy of $434 \mathrm{eV}$ via the PREC $=$ Accurate setting. Total forces were checked and found to be still below the chosen force cutoff limit. An implicit solvation model $^{51}$ was used to reproduce the effects of an acetonitrile solvent. To do this a relative permittivity of 36.64 was used. This was found to have minor effects on the highest occupied molecular orbital (HOMO) and lowest unoccupied molecular orbital (LUMO) levels. The HOMO/LUMO eigenvalues were calculated first using the PBE functional and then using the Heyd-Scuseria-Ernzerhof hybrid functional (HSE06). ${ }^{52}$ This hybrid functional was used as it provides a correction to the PBE functional at the direct exchange term of the exchangecorrelation potential. This resulted in better agreement with the experimental data for the frontier energy states (HOMO, LUMO) and optical absorption spectra.

\section{Materials, fabrication, and characterization of OLEDs}


Materials: Patterned indium tin oxide (ITO) coated glass substrates with a sheet resistance of 15 $\Omega \emptyset$ were purchased from Lumtech Corp. The hole injection material poly(3,4-ethylenedioxythiophene)-poly(styrene sulfonate) (PEDOT: PSS) was purchased from Heraeus (Clevios AI 4083). Highly pure sublimed grade hole transporting material di-[4-( $N, N$-ditolyl-amino)phenyl]cyclohexane (TAPC), electron transporting materials, 2,2',2"-(1,3,5-benzinetriyl)-tris(1phenyl-1-H-benzimidazole) (TPBi) and 1,3-bis(3,5-dipyrid-3-yl-phenyl)benzene (BmPyPB), and a molecular host material 4,4'-bis( $N$-carbazolyl)-1,1'-biphenyl (CBP) were also purchased from Lumtech Corp. The electron injection materials lithium fluoride (LiF) (99.98\%) was purchased from Acros Organics. Moreover, 99.999\% pure Aluminum (Al) ingots were purchased from Kurt J. Lesker Co. Ltd. The sublimed-grade transport and host materials were used directly without further purification.

Device fabrication: For solution-process devices, firstly, a $35 \mathrm{~nm}$ aqueous solution of PEDOT:PSS hole transporting layer (HTL) is spin-coated (4000 rpm for 20s) on pre-cleaned ITO coated glass substrates. Then PEDOT:PSS layer is annealed at $125^{\circ} \mathrm{C}$ for $30 \mathrm{~min}$. in ambient atmosphere. Later on these substrates were transferred into a glove box for subsequent deposition. The green emission layers (EMLs), consisting mixtures of 5, 10, and $15 \mathrm{wt} \%$ synthesized $\operatorname{Ir}(\mathrm{III})$ complexes, including $\operatorname{Ir}(\mathrm{ppy})_{2} \mathrm{~L} 1$, $\operatorname{Ir}(\mathrm{ppy})_{2} \mathrm{~L} 2$, and $\operatorname{Ir}(\mathrm{ppy})_{2} \mathrm{~L} 3$, together with the CBP host, were then spin-coated at $2500 \mathrm{rpm}$ for $20 \mathrm{~s}$. Finally, these substrates were transferred into a high vacuum chamber for succeeding layers, a $35 \mathrm{~nm}$ TPBi as electrontransporting layer (ETL), and a $1 \mathrm{~nm}$ LiF as electron injection layer, which were deposited by thermal evaporation at $1 \times 10^{-7}$ mbar. Finally, a $100 \mathrm{~nm} \mathrm{Al}$ cathode layer was evaporated with a shadow mask that results an active area of $25 \mathrm{~mm}^{2}$. On the other hand, the dry-processed phosphorescent samples were prepared by sequentially depositing of ITO (120 nm)/TAPC (40 
$\mathrm{nm}) / \mathrm{EML}(20 \mathrm{~nm}) / \mathrm{BmPyPB}(35 \mathrm{~nm}) / \mathrm{LiF}(1 \mathrm{~nm}) / \mathrm{Al}(100 \mathrm{~nm})$ using the thermal evaporation. Before thermal evaporation, the EMLs were prepared by the solution-premixing of 5, 10, and 15 $\mathrm{wt} \%$ of $\operatorname{Ir}(\mathrm{ppy})_{2} \mathrm{~L} 1$ emitter in to the CBP host matrix.

Device characterization: Current density-voltage-luminance $(J-V-L)$ characteristics of the OLEDs were measured using a Keithley 2400 source meter and a Konica Minolta CS100 luminance meter. The electroluminance (EL) spectra of all the devices were recorded by using a Photo Research PR 655 spectrometer. The external quantum efficiency, $\eta_{E Q E}$, was then estimated by calculating the total number of emitted photons divided by the total number of injected electrons, based on the assumption of the Lambertian-type emission pattern.

\section{Acknowledgments}

S.K. and C.J.S. are grateful for financial support from ETH startup funding. K.R.S. and A.C.V. acknowledge Department of Science and Technology (DST), Technology system group (TSG), New Delhi (No. DST/TSG/PT/2011/194G) for financial support and the Head, Department of Chemistry, Sardar Patel University, SICART, Vallabha Vidyanagar, Anand, SAIF, and IIT Mumbai for providing instrumental facilities for materials characterizations. E.J.G.S. thanks the financial support from the Energy PRP funded by Queen's University Belfast as well as the PhD studentship for R.L. (EPSRC funded). E.J.G.S. acknowledges the use of computational resources from the UK national high performance computing service, ARCHER, for which access was obtained via the UKCP consortium and funded by EPSRC grant ref EP/K013564/1; and the Extreme Science and Engineering Discovery Environment (XSEDE), supported by NSF grants number TG-DMR120049 and TG-DMR150017. The Queen's Fellow Award through the startup grant number M8407MPH is also acknowledged. 


\section{Supporting Information}

Thermal, photophysical, and electrochemical characteristics, DFT calculation for the optical absorption and corresponding energy levels, NMR, mass and IR spectra of Ir (III) complexes with supplementary tables including calculated dipole transition matrix elements $\alpha$ (a.u.), and excitation energies $\Delta \mathrm{E}$ for $\mathrm{Ir}$ (III) complexes are supplied as Supporting Information. The Supporting Information is available free of charge on the ACS Publications website at DOI:

\section{References}

1. Service, R. F. Organic LEDs look forward to a bright, white future, Science 2005, 310, 17621763.

2. Sasabe, H.; Kido, J. Development of high performance OLEDs for general lighting, J. Mater. Chem. C, 2013, 1, 1699-1707.

3. Jou, J. H.; Kumar, S.; Agrawal, A.; Li, T. H.; Sahoo, S. Approaches for fabricating high efficiency organic light emitting diodes, J. Mater. Chem. C, 2015, 3, 2974-3002.

4. Yersin, H. "Highly Efficiency OLEDs with Phosphorescent Materials", Wiley-VCH Verlag GmbH \& Co. KGaA, ISBN 978-3-527-40594-7.

5. Tao, Y.; Yang, C.; Qin, J. Organic host materials for phosphorescent organic light-emitting diodes, Chem. Soc. Rev., 2011, 40, 2943-2970.

6. Kulkarni, A. P.; Tonzola, C. J.; Babel, A.; Jenekhe, S. A. Electron transport materials for organic light-emitting diodes, Chem. Mater., 2004, 16, 4556-4573.

7. Gather, M. C.; Reineke, S. Recent advances in light outcoupling from white organic lightemitting diodes, J. Photon. Energy. 2015, 5, 057607. 
8. Brütting, W.; Frischeisen, J.; Schmidt, T. D.; Scholz, B. J.; Mayr, C. Device efficiency of organic light-emitting diodes: Progress by improved light outcoupling, Phys. Status Solidi A, 2013, 210, 44-65.

9. (a) Baldo, M. A.; O’Brien, D. F.; You, Y.; Shoustikov, A.; Sibley, S.; Thompson, M. E.; Forrest, S. R. Highly efficient phosphorescent emission from organic electroluminescent devices, Nature 1998, 395, 151-154. (b) Adachi, C.; Baldo, M. A.; Thompson, M. E.; Forrest, S. R. Nearly 100\% internal phosphorescence efficiency in an organic light-emitting device, J. Appl. Phys. 2001, 90, 5048. (c) Sun, Y.; Giebink, N. C.; Kanno, H.; Ma, B.; Thompson, M. E.; Forrest, S. R. Management of singlet and triplet excitons for efficient white organic light-emitting devices, Nature 2006, 440, 908-912. (d) Reineke, S.; Lindner, F.; Schwartz, G.; Seidler, N.; Walzer, K.; Lüssem, B.; Leo, K. White organic light-emitting diodes with fluorescent tube efficiency, Nature 2009, 459, 234-238. (e) Xiao, L.; Chen, Z.; Qu, B.; Luo, J.; Kong, S.; Gong, Q.; Kido, J. Recent progresses on materials for electrophosphorescent organic light-emitting devices, Adv. Mater. 2011, 23, 926-952.

10. (a) Sun, H.; Liu, S.; Lin, W.; Zhang, K. Y.; Lv, W.; Huang, X.; Huo, F.; Yang, H.; Jenkins, G.; Zhao, Q.; Huang, W. Smart responsive phosphorescent materials for data recording and security protection, Nat. Comm., 2014, 5, 3601. (b) Zhang, K. Y.; Chen, X.; Sun, G.; Zhang, T.; Liu, S.; Zhao, Q.; Huang, W. Utilization of Electrochromically luminescent transition-metal complexes for erasable information recording and temperature-related information protection, Adv. Mater., 2016, 28, 7137-7142. (c) Lin, W.; Zhao, Q.; Sun, H.; Zhang, K. Y.; Yang, H.; Yu, Q.; Zhou, X.; Guo, S.; Liu, S.; Huang, W. An electrochromic phosphorescent iridium (III) complex for information recording, encryption, and decryption, Adv. Opt. Mater., 2015, 3, 368-375. (d) Tao, P.; Miao, Y.; Zhang, Y. Wang, K.; Li, H.; Li, L.; Li, X.; Yang, T.; Zhao, Q.; Wang, H.; Liu; S.; Zhou, X.; Xu, B.; Huang, W. Highly efficient 
thienylquinoline-based phosphorescent iridium(III) complexes for red and white organic lightemitting diodes, Org. Electron., 2017, 45, 293-299.

11. (a) Grushin, V. V.; Herron, N.; LeCloux, D. D.; Marshall, W. J.; Petrov, V. A.; Wang, Y. New, efficient electroluminescent materials based onorganometallic Ir complexes, Chem. Commun., 2001, 1494-1495. (b) Lamansky, S.; Djurovich, P.; Murphy, D.; Abdel-Razzaq, F.; Lee, H. E.; Adachi, C.; Burrows, P. E.; Forrest S. R.; and Thompson, M. E. Highly phosphorescent bis-cyclometalated Iridium complexes: Synthesis, photophysical characterization, and use in organic light emitting diodes, J. Am. Chem. Soc., 2001, 123, 4304-4312. (c) Yang, C. H.; Cheng, Y.-M.; Chi, Y.; Hsu, C.-J.; Fang, F.-C.; Wong, K.-T.; Chou, P.-T.; Chang, C.-H.; Tsai M.-H.; Wu, C.-C. Blue-emitting heteroleptic iridium(III) complexes suitable for high-efficiency phosphorescent OLEDs, Angew. Chem., Int. Ed., 2007, 46, 2418-2421.

12. (a) Chi, Y. and Chou, P-T. Transition-metal phosphors with cyclometalating ligands: fundamentals and applications, Chem. Soc. Rev. 2010, 39, 638-655. (b) Mi, B. X.; Wang, P. F.; Gao, Z. Q.; Lee, C. S.; Lee, S. T.; Hong, H. L.; Chen, X. M.; Wong, M. S.; Xia, P. F.; Cheah, K. W.; Chen, C. H.; Huang, W. Strong luminescent Iridium complexes with $\mathrm{C}^{\wedge} \mathrm{N}=\mathrm{N}$ structure in ligands and their potential in efficient and thermally stable phosphorescent OLEDs, Adv. Mater. 2009, 21, 339-343. (c) Suzuril, Y.; Oshiyama, T.; Ito, H.; Hiyama, K.; Kita, H. Phosphorescent cyclometalated complexes for efficient blue organic light-emitting diodes, Sci. Technol. Adv. Mater. 2014, 15, 054202. (d) Zhou, G.; Ho, C.-L.; Wong, W.-Y.; Wang, Q.; Ma, D.; Wang, L.; Lin, Z.; Marder, T. B.; Beeby, A. Manipulating charge-transfer character with electron-withdrawing main-group moieties for the color tuning of iridium electrophosphors, Adv. Mater. 2008, 18, 499-511. (e) Murawski, C.; Leo, K.; Gather, M. C. Efficiency roll-off in organic light-emitting diodes, Adv. Mater. 2013, 25, 6801-6827. 
13. (a) Yang, C. L.; Zhang, X. W.; You, H.; Zhu, L. Y.; Chen, L. Q.; Zhu, L. N.; Tao, Y. T.; Ma, D. G.; Shui, Z. G.; Qin, J. G. Tuning the energy level and photophysical and electroluminescent properties of heavy metal complexes by controlling the ligation of the metal with the carbon of the carbazole unit, Adv. Funct. Mater. 2007, 17, 651-661. (b) Lin, C. H.; Chang, Y. Y.; Hung, J. Y.; Lin, C. Y.; Chi, Y.; Chung, M. W.; Lin, C. L.; Chou, P. T.; Lee, G. H.; Chang, C. H.; Lin, W. C. Iridium(III) complexes of a dicyclometalated phosphite tripod ligand: strategy to achieve blue phosphorescence without fluorine substituents and fabrication of OLEDs, Angew. Chem., Int. Ed. 2011, 50, 3182-3186. (c) Lu, K. Y.; Chou, H. H.; Hsieh, C. H.; Yang, Y. H. O.; Tsai, H. R.; Tsai, H. Y.; Hsu, L. C.; Chen, C. Y.; Chen, I. C.; Cheng, C. H. Wide-Range color tuning of iridium biscarbene complexes from blue to red by different $\mathrm{N}^{\wedge} \mathrm{N}$ ligands: an alternative route for adjusting the emission colors, Adv. Mater. 2011, 23, 4933-4937. (d) Lee, S.; Lee, S. O.; Shin, H.; Yun, H. J.; Yang, K.; Kwon, S. K.; Kim, J. J.; Kim, Y. H. Deep-blue phosphorescence from perfluoro carbonyl-substituted iridium complexes, J. Am. Chem. Soc. 2013, 135, 14321-14328.

14. Baldo, M. A.; Lamansky, S.; Burrows, P. E.; Thompson, M. E.; Forrest, S. R. Very highefficiency green organic light-emitting devices based on electrophosphorescence, Appl. Phys. Lett., 1999, 75, 4-6.

15. Tao, Y. T.; Wang, Q. A.; Yang, C. L.; Zhong, C.; Qin, J. G.; Ma, D. G. Multifunctional triphenylamine/oxadiazole hybrid as host and exciton-blocking material: High efficiency green phosphorescent OLEDs using easily available and common materials, Adv. Fucnt. Mater., 2010, 20, 2923-2929. 
16. Kim, Y.; Park, S.; Lee, Y. H.; Jung, J.; Yoo, S.; Lee, M. H., Homoleptic tris-cyclometalated iridium complexes with substituted o-carboranes: Green phosphorescent emitters for highly efficient solution-processed organic light-emitting diodes, Inorg. Chem., 2016, 55, 909-917.

17. Xu, Q.-L.; Liang, X.; Zhang, S.; Jing, Y.-M.; Liu, X.; Lu, G.-Z.; Zheng, Y.-X.; Zuo, J.-L. Efficient OLEDs with low efficiency roll-off using iridium complexes possessing good electron mobility, J. Mater. Chem. C, 2015, 3, 3694-3701.

18. (a) Zhu, Y. C.; Zhou, L.; Li, H. Y.; Xu, Q. L.; Teng, M. Y.; Zheng, Y. X.; Zuo, J. L.; Zhang, H. J.; You, X. Z. Highly efficient green and blue-green phosphorescent OLEDs based on iridium complexes with the tetraphenylimidodiphosphinate ligand, Adv. Mater. 2011, 23, 4041-4046. (b) Li, H. Y.; Zhou, L.; Teng, M. Y.; Xu, Q. L.; Lin, C.; Zheng, Y. X.; Zuo, J. L.; Zhang, H. J.; You, X. Z. Highly efficient green phosphorescent OLEDs based on a novel iridium complex, J. Mater. Chem. C, 2013, 1, 560-565.

19. Jou, J. H.; Li, C. J.; Shen, S. M.; Peng, S. H.; Chen, Y. L.; Jou, Y. C.; Hong, J. H.; Chin, C. L.; Shyue, J. J.; Chen, S. P.; Li, J. Y.; Wang, P. H.; Chen, C. C. Highly efficient green organic light emitting diode with a novel solution processable iridium complex emitter, $J$. Mater. Chem. C, 2013, 1, 4201-4208.

20. Tong, B.; Ku, H.-Y.; Chen, I.-J.; Chi, Y.; Kao, H.-C.; Yeh, C.-C.; Chang, C.-H.; Liu, S.-H.; Lee, G.-H.; Chou, P.-T. Heteroleptic Ir(III) phosphors with bis-tridentate chelating architecture for high efficiency OLEDs, J. Mater. Chem. C, 2015, 3, 3460-3471.

21. Zhang, F.; Li, W.; Yu, Y.; Jing, Y.; Ma, D.; Zhang, F.; Li S., Cao, G.; Li, Z.; Guo, G.; Wei, B.; Zhang, D.; Duan, L.; Li, C.; Feng, Y.; Zhai, B. Highly efficient green phosphorescent organic light-emitting diodes with low efficiency roll-off based on iridium(III) complexes bearing oxadiazol-substituted amide ligands, J. Mater. Chem. C, 2016, 4, 5469-5475. 
22. Jou, J.-H.; Yang, Y.-M.; Chen, S.-Z.; Tseng, J.-R.; Peng, S.-H.; Hsieh, C.-Y.; Lin, Y.-X.; Chin, C.-L.; Shyue, J.-J.; Sun, S.-S.; Chen, C.-T.; Wang, C.-W.; Chen, C.-C.; Lai S.-H.; Tung, F.-C. High-efficiency wet- and dry-processed green organic light emitting diodes with a novel Iridium complex-based emitter, Adv. Opt. Mater., 2013, 1, 657-667.

23. Benjamin, H.; Fox, M. A.; Batsanov, A. S.; Al-Attar, H. A.; Li, C.; Ren, Z.; Monkman, A. P.; Bryce, M. R., Pyridylpyrazole $N^{\wedge} N$ ligands combined with sulfonyl-functionalised cyclometalating ligands for blue-emitting iridium(III) complexes and solution-processable PhOLEDs, Dalton Trans., 2017, 46, 10996-11007.

24. Wallace, D. J.; Straley, J. M. Synthesis of 5-Oxo-2-pyrazoline-4-carboxaldehydes, J. Org. Chem. 1961, 26, 3825-3826.

25. Surati, K. R.; Thaker, B. T. Synthesis, spectroscopic and thermal investigation of Schiff-base complexes of $\mathrm{Cu}(\mathrm{II})$ derived from heterocyclic $\beta$-diketone with various primary amines, $J$. Coord. Chem. 2006, 59, 1191-1202.

26. Nonoyama, M. Benzo[H]quinolin-10-yl-N Iridium (III) complexes, M. Bull. Chem. Soc. Jpn. 1974, 47, 767-768.

27. Umamahesh, B.; Karthikeyan, N. S.; Sathiyanarayanan, K. I.; Malicka, J. M.; Cocchi, M. Tetrazole iridium(III) complexes as a class of phosphorescent emitters for high-efficiency OLEDs, J. Mater. Chem. C, 2016, 4, 10053-10060.

28. Yersin, H. Highly Efficiency OLEDs with Phosphorescent Materials, Wiley-VCH Verlag GmbH \& Co. KGaA, ISBN 978-3-527-40594-7.

29. Colombo, M. G.; Hauser, A.; Gudel, H. U. Competition between ligand centered and charge transfer lowest excited states in bis cyclometalated $\mathrm{Rh}^{3+}$ and $\mathrm{Ir}^{3+}$ complexes, Top. Curr. Chem., 1994, 171, 143-171. 
30. Reineke, S.; Walzer, K.; Leo, K. Triplet-exciton quenching in organic phosphorescent lightemitting diodes with Ir-based emitters, Phys. Rev. B 2007, 75, 125328.

31. Jou, J.-H.; Kumar; S.; Tavgeniene, D.; An, C-C.; Fang, P-H.; Zaleckas, E.; Grazulevicius, J. V.; Grigalevicius, S. Wet-process feasible novel carbazole-type molecular host for high efficiency phosphorescent organic light emitting diodes, J. Mater. Chem. C, 2014, 2, 87078714.

32. Sprouse, S.; King, K. A.; Spellane, P. J.; Watts, R. J., Photophysical effects of metal-carbon $\sigma$ bonds in ortho-metalated complexes of $\mathrm{Ir}(\mathrm{III})$ and $\mathrm{Rh}$ (III), J. Am. Chem. Soc. 1984, 106, 6647-6653.

33. King, K. A.; Spellane, P. J.; Watts, R. J. Excited-state properties of a triply ortho-metalated iridium(III) complex, J. Am. Chem. Soc. 1985, 107, 1431-1432.

34. Tao, P.; Li, W.-L.; Zhang, J.; Gao, S.; Zhao, Q.; Wang, H.; Wei, B.; Liu, S.-J.; Zhou, X.-H.; Yu, Q.; Xu, B.-S.; Huang, W., Facile synthesis of highly efficient lepidine-based phosphorescent Iridium(III) complexes for yellow and white organic light-emitting diodes, Adv. Funct. Mater., 2016, 26, 881-894.

35. Colombo, M. G.; Brunold, T. C.; Riedener, T.; Gudel, H. U.; Fortsch, M.; Burgi, H. B., Facial tris cyclometalated rhodium(III) and iridium(III) complexes: their synthesis, structure, and optical spectroscopic properties, Inorg. Chem. 1994, 33, 545-550.

36. Tamayo, A. B.; Alleyne, B. D.; Djurovich, P. I.; Lamansky, S.; Tsyba, I.; Ho, N. N.; Bau, R.; Thompson, M. E.; Synthesis and characterization of facial and meridional tris-cyclometalated iridium(III) complexes, J. Am. Chem. Soc. 2003, 125, 7377-7387.

37. (a) Zhao, J.-H.; Hu, Y.-X.; Dong, Y.; Xia, X.; Chi, H.-J.; Xiao, G.-Y.; Li, X.; Zhang, D.-Y. Novel bluish green benzimidazole-based iridium(III) complexes for highly efficient 
phosphorescent organic light-emitting diodes, New J. Chem., 2017, 41, 1973. (b) Zhou, Y.; Li, W.; Liu, Y.; Zeng, L.; Su, W.; Zhou, M., Substituent effect of ancillary ligands on the luminescence of bis[4,6-(di-fluorophenyl)-pyridinato-N,C2']iridium(III) complexes, Dalton Trans. 2012, 41, 9373-9381.

38. (a) Chang, C.-J.; Yang, C.-H.; Chen, K.; Chi, Y.; Shu, C.-F.; Ho, M.-L.; Yeh, Y.-S.; Chou, P.-T. Color tuning associated with heteroleptic cyclometalated $\operatorname{Ir}(\mathrm{III})$ complexes: influence of the ancillary ligand, Dalton Trans., 2007, 0, 1881. (b) Nazeeruddin, M. K.; Humphry-Baker, R.; Berner, D.; Rivier, S.; Zuppiroli, L.; Grätzel, M. Highly phosphorescence iridium complexes and their application in organic light-emitting devices, J. Am. Chem. Soc., 2003, 125, 8790. (c) Hwang, F.-M.; Chen, H.-Y.; Chen, P.-S.; Liu, C.-S.; Chi, Y.; Shu, C.-F.; Wu, F.-I.; Chou, P.-T.; Peng, S.-M.; Lee, G.-H. Iridium(III) complexes with orthometalated quinoxaline ligands: Subtle tuning of emission to the saturated red color, Inorg. Chem., 2005, 44, 1344. (d) Chen, L.; You, H.; Yang, C.; Ma, D.; Qin, J. Novel, highly efficient blueemitting heteroleptic iridium(III) complexes based on fluorinated 1,3,4-oxadiazole: tuning to blue by dithiolate ancillary ligands, Chem. Comm., 2007, 0, 1352.

39. Cai, Q.; Scullion, D.; Falin, A.; Watanabe, K.; Taniguchi, T.; Chen, Y.; Santos, E. J. G.; Li, L. H., Raman signature and phonon dispersion of atomically thin boron nitride, Nanoscale, 2017, 9, 3059-3067.

40. Kim, K. H.; Lee, S.; Moon, C. K.; Kim, S. Y.; Park, Y. S.; Lee, J. H.; Lee, J. W.; Huh, J.; You, Y.; Kim, J. Y., Phosphorescent dye-based supramolecules for high-efficiency organic light-emitting diodes, Nat. Comm. 2014, 5, 4769. 
41. Liaptsis, G.; Meerholz, K., Crosslinkable TAPC-based hole-transport materials for solutionprocessed organic light-emitting diodes with reduced efficiency roll-off, Adv. Funct. Mater., 2013, 23, 359-365.

42. Niu, Y. H.; Liu, M. S.; Ka, J. W.; Bardeker, J.; Zin, M. T.; Schofield, R.; Chi, Y.; Jen, A. K. Y. Crosslinkable hole-transport layer on conducting polymer for high-efficiency white polymer light-emitting diodes, Adv. Mater., 2007, 19, 300-304.

43. Perrin, D.D.; Armarego, W. L. F.; Perrin, D. R. Purification of Laboratory Chemicals, 2nd ed., Pergamon Press: 1981; p. 98.

44. Gordon, A.; Ford, R.; Khimika, S. A. Handbook of Practical Data, Techniques and References, John Wiley and Sons, Moscow, 1976; p. 246, 248.

45. (a) Kresse, G.; Hafner, J. Ab initio molecular dynamics for open-shell transition metals, Phys. Rev. B 1993, 48, 13115. (b) Kresse, G.; Furthmuller, J. Efficient iterative schemes for ab initio total-energy calculations using a plane-wave basis set, Phys. Rev. B 1996, 54, 11169.

46. Clark, S. J.; Segall, M. D.; Pickard, C. J.; Hasnip, P. J.; Probert, M. I. J.; Refson, K.; Payne, M. C. First Principles methods using CASTEP, Z. Kristallogr., 2005, 220, 567.

47. Perdew, J. P.; Burke, K.; Ernzerhof, M. Generalized gradient approximation made simple, Phys. Rev. Lett. 1996, 77, 3865.

48. Pfrommer, B. G.; Cote, M.; Louie, S.G.; Cohen. M. L. Generation of turbulent inflow data for spatially-developing boundary layer simulations, J. Comput. Phys., 1997, 131, 233-258.

49. Blöchl, P. E. Projector augmented-wave method, Phys. Rev. B, 1994, 50, 17953.

50. Kresse G.; Joubert, D., From ultrasoft pseudopotentials to the projector augmented-wave method, Phys. Rev. B 1999, 59, 1758. 
51. Mathew, K.; Sundararaman, R.; Letchworth-Weaver, K.; Arias, T. A.; Hennig, R. G., Implicit solvation model for density-functional study of nanocrystal surfaces and reaction pathways, J. Chem. Phys. 2014, 140, 084106.

52. a) Heyd, J.; Scuseria, G. E.; Ernzerhof, M., Hybrid functionals based on a screened Coulomb potential, J. Chem. Phys. 2003, 118, 8207; b) Heyd, J.; Scuseria, G. E.; Ernzerhof, M., Erratum: "Hybrid functionals based on a screened Coulomb potential" [J. Chem. Phys. 118, 8207 (2003)], J. Chem. Phys. 2006, 124, 219906; c) Heyd, J.; Scuseria, G. E., Efficient hybrid density functional calculations in solids: assessment of the Heyd-Scuseria-Ernzerhof screened Coulomb hybrid functional, J. Chem. Phys. 2004, 121, 1187. 


\section{For Table of Contents Only}

We design and synthesize a heteroleptic iridium (Ir) complex, $\operatorname{Ir}(\mathrm{ppy})_{2} \mathrm{~L} 1$, using an ancillary ligand, 1-(2-chlorophenyl)-5-hydroxy-3-methyl-1H-pyrazole-4-carbaldehyde (L1). The photophysical and electrochemical properties were systematically characterized, followed by comparing with those predicted by density functional theory simulations. By using 4,4'bis(carbazole-9-yl)biphenyl as the host material, we demonstrate high current efficiencies of 64 $\mathrm{cd} \mathrm{A}^{-1}$ and $40 \mathrm{~cd} \mathrm{~A}^{-1}$ at $100 \mathrm{~cd} \mathrm{~m}^{-2}$ in its vacuum-evaporated and solution-processed organic light-emitting devices.

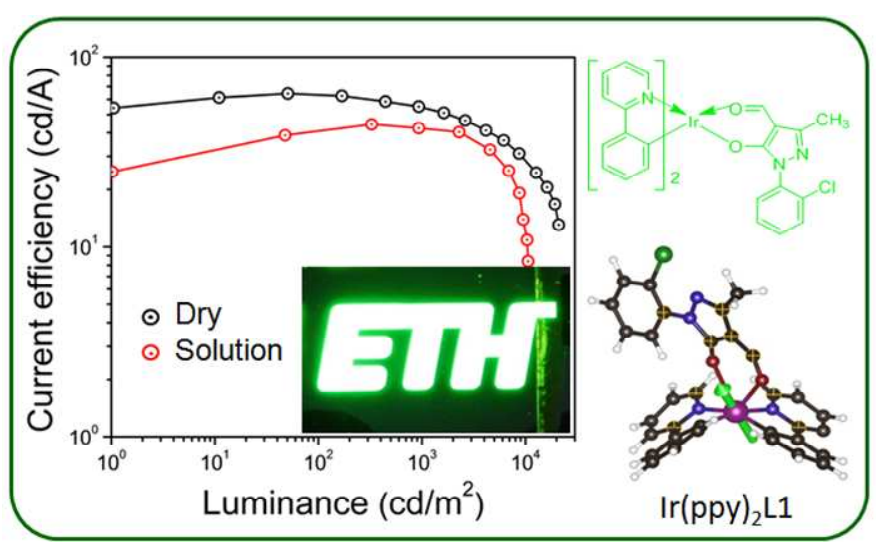

